\title{
The Use of Ocean-Colour Data to Estimate Chl-a Trends in European Seas
}

\author{
Giovanni Coppini ${ }^{1,2}$, Vladyslav Lyubarstev ${ }^{1}$, Nadia Pinardi $^{3}$, Simone Colella ${ }^{4}$, \\ Rosalia Santoleri ${ }^{4}$, Trine Christiansen ${ }^{5}$ \\ ${ }^{1}$ Centro Euro Mediterraneo per i Cambiamenti Climatici, Lecce, Italy \\ ${ }^{2}$ Istituto Nazionale di Geofisica e Vulcanologia, Bologna, Italy \\ ${ }^{3}$ CIRSA, University of Bologna, Ravenna, Italy \\ ${ }^{4}$ National Research Council, Institute of Atmospheric Sciences and Climate, Rome, Italy \\ ${ }^{5}$ European Environment Agency, Copenhagen, Denmark \\ Email: giovanni.coppini@cmcc.it
}

Received June 6, 2013; revised July 8, 2013; accepted July 20, 2013

Copyright (C) 2013 Giovanni Coppini et al. This is an open access article distributed under the Creative Commons Attribution License, which permits unrestricted use, distribution, and reproduction in any medium, provided the original work is properly cited.

\begin{abstract}
Ocean-colour remote-sensing products have been used to estimate Chl-a trends in European seas with the aim to develop a new indicator based on ocean-colour data for the European Environment Agency (EEA). The new indicator, called CSI023(+), derived from satellite ocean-colour products from the MyOcean Marine Core Service (www.myocean.eu) has been defined and calculated. In our analysis, we have used 3 MyOcean satellite products: 2 global satellite products (SeaWiFS and a merged product) and one regional (adjusted to specific regional Mediterranean conditions) ocean-colour product. We have evaluated the differences among the 3 different products in estimating Chl-a trends. CSI023(+) complements the EEA CSI023 indicator for eutrophication based on chlorophyll-a (Chl-a) in-situ observations. Analysis has revealed the potential of ocean colour as a CSI023(+) indicator to detect large-scale, and in some cases, even local-scale, changes and decreasing trends of Chl-a were observed throughout the Black Sea, the Eastern Mediterranean, the southern part of the Western Mediterranean, the English Channel and the north part of the North Sea. Large areas with increasing trends were observed in the Bay of Biscay, in the North-East Atlantic regions of Ireland and the UK, in the northern part of the North Sea, in the Kattegat and in the Baltic. Specific analysis has been performed in the Mediterranean coastal areas using regional products to investigate local scale results. Validation of ocean-colour products has been carried out through comparison with observations of the Eionet EEA database. The validation results highlight that regional products produced with regional algorithms are recommended for the future.
\end{abstract}

Keywords: Chlorophyll-a; Trends; Eutrophication; Ocean Colour; In-Situ; Indicator

\section{Introduction}

A recent review [1] has presented an overview of eutrophication indicators for assessing environmental status within the European Marine Strategy Framework Directive (MSFD). Several studies presented the use Chl-a, used as a proxy for phytoplankton biomass, as an indicator of eutrophication [2-13]. Chl-a alone is not enough to estimate eutrophication processes [1] and to provide a complete picture of eutrophic conditions should also be included (i.e. changes in community composition) but Chl-a is one of the relevant biological indicators [1] suitable to describe the status of eutrophication since Chl-a will increase due to increased nutrient availability.

Most eutrophication assessment methods recognize that the immediate biological response is increased pri- mary production reflected as increased chlorophyll a (Chl-a) and/or macroalgal abundance [5,13-16].

Eutrophication in marine waters has been a management concern in Europe over recent decades. Legislative frameworks have been set up, including the Water Framework Directive (WFD) and the MSFD on transitional and marine waters. Moreover, several other EU Directives are aimed at reducing nutrient loads and impacts. These include the Nitrates Directive (91/676/EEC); the Urban Waste Water Treatment Directive (91/271/EEC) as well as the Integrated Pollution Prevention and Control Directive (96/61/EEC). Measures also arose from a number of other international initiatives and policies (i.e. UN Global Programme of Action for the Protection of the Marine Environment against Land-Based Activities; the Medi- 
terranean Action Plan (MAP); the Helsinki Convention (HELCOM) for the Baltic Sea; the OSPAR Convention for the North East Atlantic as well as the Bucharest Convention for the Black Sea.

In the European and international framework, EEA has set up an indicator based on in-situ Chl-a trends to monitor eutrophication in the European seas; this is referred to as CSI023 (Chlorophyll in transitional, coastal and marine waters) in the EEA system. For a complete overview of the indicator, please refer to the following web site: http://www.eea.europa.eu/data-and-maps/indicators/chlor ophyll-in-transitional-coastal-and/chlorophyll-in-transitio nal-coastal-and-3.

The objective of the CSI023 indicator is to demonstrate the effects of policy measures taken to reduce loading of nitrogen and phosphates from rivers that affect primary production biomass in the coastal zones. CSI023 is calculated from Chl-a in-situ data. The last EEA assessment was performed in March 2013, and its results were presented in terms of concentration of Chl-a in the European seas and CSI023 from 1985 to 2010.

CSI023 is based on measurements collected using fluorometers are given at selected coastal stations, providing an accurate measure of Chl-a. In this regard, two main problems relating to in-situ Chl-a dataset were presented, which are: a low temporal and spatial resolution as well as the poor coverage, especially in Southern European seas. We have therefore identified the challenge of integrating the in-situ dataset with ocean-colour products to complement the former and provide EEA and Member States with valuable information for eutrophication assessment.

Measurements using satellite radiometers of waterleaving radiance in the visible range (ocean colour) can today be used to determine Chl-a concentration, which is an indicator of algal photosynthetic activity and thus related to phytoplankton biomass. Chl-a can now be estimated from ocean-colour data at daily frequencies and 250 m horizontal resolutions.

Ocean-colour satellite products are now available from SeaWiFS, MERIS-Envisat and MODIS-aQUA sensors. The future Sentinel-3 GMES satellite will also have an ocean-colour sensor ensuring continuous monitoring for the period 2015-2030. The first ocean-colour sensor, CZCS, was in operation from approximately 1980 to 1986 , afterwards the MOS sensor was from approximately 1997 to 2004 and OCTS from October 1996 to June 1997, finally, SeaWiFS, only started in 1997.

Estimation of Chl-a from ocean colour is an integral value over the e-folding scale of light in water. The optical properties of oceanic waters can be classed into Case 1 or Case 2 waters [17-19]. In our analysis we used global and regional (adjusted to specific regional Mediterranean conditions) ocean-colour products, both devel- oped for Case 1 waters since only these types of products were available.

A first attempt of evaluating Chl-a trend was performed by using CZCS products [20] and demonstrated the importance of ocean colour data in assessing Chl-a trends and studying the ocean carbon cycle, Recent studies underlined the importance of maintaining continuous, intercalibrated, climate-quality satellite data records for climate-change detection and attribution studies [21]. Similar requirements are underlined also from our study that highlights the importance of intercalibrated and consistent merged products.

The analyses of temporal variability of derived apparent optical properties in European seas are conducted in [22] on the SeaWiFS dataset (1997-2007) and the Chl-a trends presented in our study were consistent with the products presented in [22] such as reflectance band ratio trends. Moreover, inter-annual variations in the SeaWiFS global Chl-a concentration (1997-2007) are presented in term of annual trends in [23] for the Global Ocean. A direct comparison with our results cannot be presented because we focused on the summer period trend analysis for consistency with existing EEA CSI023 and specifically on European Seas, while [23] considered the trends of the full year period.

Compared to previous work that only took into account remote sensing [22,23] or in situ [5,13-16] the new approach presented in our study focuses on integrating in-situ and ocean colour data to assess the differences in estimating Chl-a concentration and trends and to better respond to the EEA need of providing an estimation of Chl-a trends in all European Seas.

This study aims to developing a methodology to complement the EEA CSI023 indicator with observations based on ocean colour from space and the indicator obtained which was named CSIO23(+).

The purpose of the study is to:

- Derive and analyse the ocean colour based trends in European seas;

- Compare ocean-colour Chl-a data and trends with insitu ones;

- Present the trends of Chl-a as CSI023(+) in the European seas for the period 1998-2009.

The study is organized as follows: Section 2 describes the satellite and in-situ data sources and defines the indicator and the Chl-a areas concept and methods; Section 3 is on the validation of datasets; Section 4 is the results; Section 5 concludes the study.

\section{Data and Methods}

\subsection{Satellite and in-Situ Data Sources}

\subsubsection{Satellite Data Sources}

We used three different MyOcean ocean-colour datasets 
(Table 1): “Global Ocean GSM-MyOcean"; “Global Ocean SeaWiFS RAN-MyOcean"; and "Med Regional SeaWiFS RAN-MyOcean".

The first dataset "Global Ocean GSM-MyOcean" was developed within the framework of GlobColour (www.globcolour.info) and it is regularly produced and distributed by the Global Monitoring for Environment and Security (GMES) MyOcean project. This is a multi sensor merged product based on SeaWiFS, AQUA and MERIS data available from MyOcean at $4 \mathrm{~km}$ resolution. The Global Ocean GSM-MyOcean has been produced using the bio-optical model-based merging procedure observed in [24,25], which combines the normalized waterleaving radiances from different sensor data sets. Over each particular pixel of a geographical grid common to SeaWiFS, AQUA and MERIS, the spectral water-leaving radiance, $\operatorname{NLw}(\lambda)$ spectra from the available sensors at that pixel are selected and combined in a single, multisource, spectrum which is then used in the inversion of the GSM01 semi-analytical ocean colour model [24]. The use of these three sensors contributed to reduce data gaps, increasing the coverage over ocean by a factor, which is nearly twice that of any single mission's observations [26]. The Global Ocean GSM-MyOcean products have been validated by [26] and by comparing them to the data sets obtained from individual missions. This product has been available since September 1997 and the timeseries is constituted of daily products delivered by MyOcean. The time frame of the dataset chosen for this research work was between 1998-2009 based on consistent processing chains for MODIS and MERIS. Only later in 2010 and 2011 the processing chains were upgraded: the NASA MODIS L2 processing has been switched from R2009.1 to R2010.0 in June 2011 and the MERIS L2 processing switched from the 2nd to the 3rd MERIS reprocessing in autumn of 2012 (see MYO-OC-PUM manual available on line at www.myocean.eu). Moreover the SeaWiFS products are associated with the latest reproc- essing performed by NASA for SeaWiFS using SeaDAS 6.1 software.

The second dataset is the "Global Ocean SeaWiFS RAN-MyOcean" Chl-a dataset. The full SeaWiFStime series, based on SeaWiFS algorithm [27] reprocessed a consistent time series of L2 input data using OC4-V4 algorithm for chlorophyll retrieval. This MyOcean product is associated with the latest reprocessing performed by NASA for SeaWiFS using SeaDAS 6.1 software. Temporal characteristics of the dataset comprises of standard mapped image monthly mean global sea surface Chl-a maps at $9 \mathrm{~km}$ resolution (L3 product) and distributed by the GMES MyOcean project. This product has been evaluated in the framework of MyOcean.

The last satellite dataset is the "Med Regional SeaWiFS RAN-MyOcean"; it is the Mediterranean regional product based on SeaWiFS data using the Mediterranean regional ocean colour algorithm for chlorophyll retrieval (MedOC4, [28]). The MedOC4 algorithm has been validated with a large in-situ bio-optical dataset for the Mediterranean area, and its performance has been compared with global algorithms such as OC4v4 for SeaWiFS, and the results show that MedOC4 is the best algorithm for satellite chlorophyll estimates in the Mediterranean [28]. The Med regional SeaWiFS RAN has been produced at once, reprocessing the entire SeaWiFS L1 time series with a single software configuration, using the latest version of calibration and ancillary data with the SeaWiFS Data Analysis System (SeaDAS) software package version 6.1 (available seadas.gsfc.nasa.gov). The description of these MyOcean Mediterranean products and the processing system and results on the products validation has been done in [19].

It is important to underline that the three MyOcean products are calibrated for open ocean waters and not specifically for coastal waters, and thus a lower performance in the coastal zone is therefore to be expected. The complexity of optical properties of the European coastal

Table 1. Overview of ocean-colour data products used in the calculation of $\operatorname{CSI023}(+)$.

\begin{tabular}{|c|c|c|c|c|c|}
\hline Dataset name/MyOcean Product Name & Domain & Spatial Resolution & $\begin{array}{c}\text { Time Frame } \\
\text { and Resolution }\end{array}$ & $\begin{array}{c}\text { Algorithm/ } \\
\text { Merging Method }\end{array}$ & Provider \\
\hline $\begin{array}{l}\text { Global Ocean } \\
\text { GSM-MyOcean/OCEANCOLOUR_GLO_CH } \\
\text { L_MERIS_MODIS_SEAWIFS_L3_L4_RAN }\end{array}$ & Global Ocean & $\begin{array}{c}1 / 24^{\circ}=2.5^{\prime} \\
\left(2.5^{\prime} \text { latitude }=4630 \mathrm{~m} ; 2.5^{\prime}\right. \\
\text { longitude }=3274 \mathrm{~m} \text { at Lat } 45 \mathrm{~N})\end{array}$ & $\begin{array}{l}\text { 09/1997-09/2009 } \\
\text { Daily }\end{array}$ & GSM & MyOcean \\
\hline $\begin{array}{c}\text { Global Ocean SeaWiFS } \\
\text { RAN-MyOcean/OCEANCOLOUR_GLO_CH } \\
\text { L_SEAWIFS_L3_RAN_OBSERVATIONS }\end{array}$ & Global Ocean & $1 / 12^{\circ}$ & $\begin{array}{c}\text { From 1997-09-01 to } \\
\text { 2010-12-31 } \\
\text { Monthly }\end{array}$ & $\begin{array}{l}\text { Standard OC4-V4 } \\
\text { Algorithm for } \\
\text { Chl-a }\end{array}$ & MyOcean \\
\hline $\begin{array}{c}\text { Med Regional SeaWiFS RAN-MyOcean } \\
\text { /OCEANCOLOUR_MED_CHL_SEAWIFS_ } \\
\text { L3_RAN_OBSERVATIONS }\end{array}$ & $\begin{array}{c}\text { Mediterranean } \\
\text { Sea }\end{array}$ & $\begin{array}{l}\text { Approximately } 1 \times 1 \mathrm{~km} \\
\text { (Latitude step: } 1131 \mathrm{~m} \text {, } \\
\text { Longitude step: } \\
45 \mathrm{~N} \rightarrow 1006 \mathrm{~m} \\
30 \mathrm{~N} \rightarrow 1245 \mathrm{~m})\end{array}$ & $\begin{array}{c}\text { From 1997-10-01 to } \\
\begin{array}{c}2009-12-31 \\
\text { Daily }\end{array}\end{array}$ & $\begin{array}{l}\text { Mediterranean- } \\
\text { MEDOC4 }\end{array}$ & $\begin{array}{l}\text { MyOcean } \\
\text { and CNR }\end{array}$ \\
\hline
\end{tabular}


zone requires the use of specialized local algorithm and processing system. Presently, they are not available in the European scale coverage. Thus, we used the MyOcean global and regional products to investigate trends in both open ocean and coastal areas of the European Seas. The availability of in-situ coastal data will be use at posterior to check potential use of MyOcean ocean colour products to estimate trends also in the coastal waters.

The trends analysis using ocean colour products should take into account how these products have been created. For a series based on one sensor, it therefore means making sure that the series have been created with one processing chain, including a consistent calibration table and calibration history [30,31]. This applies to the Med Regional SeaWiFS RAN-MyOcean and to Global Ocean SeaWiFS RAN-MyOcean. The possible problems connected with the GSM product are: the use of L2 data provided by the space agencies at the time of the operation update of the dataset that does not ensure the complete consistency of the time series and the method does not account for a specific inter-bias calibration effort in the production of the merged datasets. We are not facing the first problem because our dataset consider the period until 2009 and the upgrade of processing chains occurred later for MERIS and MODIS. Meanwhile, the second problem should be minimized because the methodology of production of the Global Ocean GSM-MyOcean merged product should take into account specific interbias calibration [26].

We have performed a specific analysis of comparing Global Ocean SeaWiFS RAN-MyOcean reprocessed dataset from 1998 to 2009 and Global Ocean GSMMyOcean to evaluate the possible problems and the differences in the estimation of the Chl-a trends. This analysis is presented in terms of summer Chl-a trends for the European Seas calculated from the Global Ocean GSM-
MyOcean and from the Global Ocean SeaWiFS RANMyOcean dataset.

\subsubsection{In-Situ Data Sources}

To validate the Global Ocean GSM-MyOcean and the Med Regional SeaWiFS RAN-MyOcean daily satellite products, we used the in-situ data collected in the framework of EEA-Eionet databank and distributed by ICES. The data consists of Chl-a profiles collected in European Seas. The in-situ dataset covers the period 1998-2009 and contains, after the removal of duplicates, 103170 profiles. For comparison with satellite dataset, we have selected the in-situ daily profiles that had a corresponding satellite data by regrinding the in-situ data on the two satellites grid Global Ocean GSM-MyOcean and the Med Regional SeaWiFS RAN-MyOcean. The total corresponding in-situ and Global Ocean GSM-MyOcean data are 8910.

In the case of the satellite regional product Med Regional SeaWiFS RAN-MyOcean in order to perform the comparison between point in-situ observations and oceancolour data we decide to search in a surrounding area of 4 grid points around each single in-situ observation. The MedOC4 algorithm was tested and validated up to value of $10 \mathrm{mg} \cdot \mathrm{m}^{-3}$ of Chl-a and therefore we masked the Chl-a data higher than the value.

The total corresponding in-situ and Med Regional SeaWiFS RAN-MyOcean data are 13611. Table 2 presents the principal information on the in-situ dataset used in the comparison with the two satellite products.

\subsection{Complementing the EEA CSI023 In-Situ Indicator}

The EEA classical CSI023 indicator is calculated based on profiles estimated by fluorometer and averaged in the

Table 2. Principal characteristics of the in-situ EEA-EIONET dataset: number of profiles and coverage in time.

\begin{tabular}{|c|c|c|}
\hline Basins & Number of Daily Profiles & Coverage in Time \\
\hline All European Seas & 8910 & January 1998-October 2009 \\
\hline Black Sea & 78 & April 1998-September 2009 \\
\hline North East-Atlantic & 647 & March 1998-May 2009 \\
\hline North Sea & 1844 & March 1998-October 2009 \\
\hline Baltic Sea & 2480 & March 1998-October 2009 \\
\hline Mediterranean Sea ${ }^{1}$ & 3861 & January 1998-December 2008 \\
\hline Mediterranean $\mathrm{Sea}^{2}$ & 13611 & January 1998-December 2008 \\
\hline
\end{tabular}

${ }^{1}$ In-situ data after re-griding on the Global Ocean GSM-MyOcean satellite product grid.

${ }^{2}$ In-situ data after re-griding on the Med Regional SeaWiFS RAN-MyOcean satellite product grid. 
summer $^{3}$ and in the first 10 metres depth at each station of sampling. The CSI023 is defined as the significant increasing or decreasing temporal trend for each station. The in-situ Chl-a estimates are provided to the EEA through the Eionet network

(http://www.eionet.europa.eu/).

The workflow chart illustrating the methodology developed to complement the EEA CSI023 indicator with observations based on ocean colour from space is presented in Figure 1. Eleven steps were identified starting from the ocean colour and in-situ data download (Step 1) to the presentation of CSI023(+) indicator (Step 11). The different aspects of the methodology illustrated in Figure $\mathbf{1}$ are presented in this Section 2 of the paper.

\subsection{CSI023(+) Indicator Definition}

CSI023(+) is computed from MyOcean ocean-colour gridded data as a temporal trend at each grid point starting from 1998. CSI023(+) consists of significant Chl-a trends

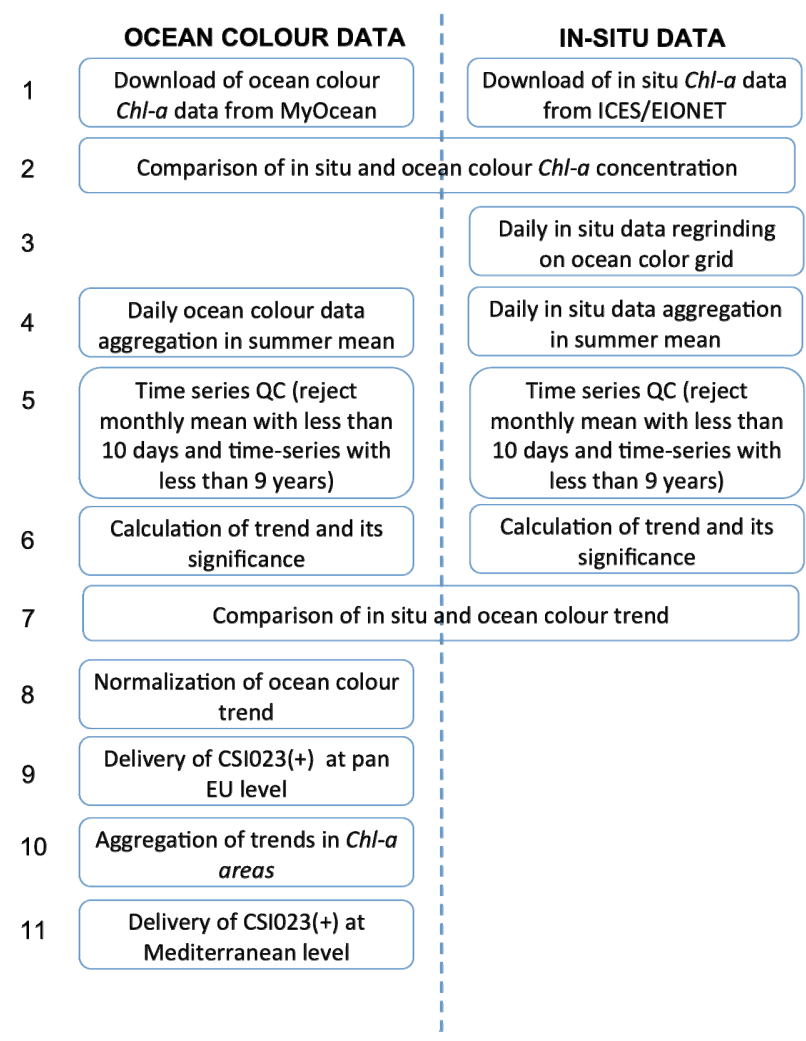

Figure 1. The workflow chart presenting the methodology developed to complement the EEA CSI023 indicator with observations based on ocean colour from space. Eleven steps are defined starting from the data download (Step 1) to the delivery of CSI023(+) (Step 11). The column on the left presents the activities performed on the ocean colour data while the column on the right presents the activities related to the in-situ data. The comparison of in-situ and ocean colour Chl-a concentration (Step 2) and Chl-a trends (Step 7) are identified as common activities. normalized by the Chl-a Standard Deviation (STD). The units of CSI023(+) are $\left(\mathrm{mg} \cdot \mathrm{m}^{-3}\left(\mathrm{mg} \cdot \mathrm{m}^{-3}\right)^{-1} \cdot \mathrm{y}^{-1}\right)$. CSI023(+) represents Chl-a annual rate of change with respect to the Chl-a variability (STD) in the specific period.

CSI023 $(+)$ is presented in the following two ways:

- "CSI023(+) Pan-European trend indicator" calculated in European seas ${ }^{4}$ based on a global ocean-colour dataset (Global Ocean GSM-MyOcean ${ }^{5}$ product);

- "CSI023(+) Chl-a areas ${ }^{6}$ trend indicator" calculated in Mediterranean Sea based on a regional ocean-colour dataset (Med Regional SeaWiFS RAN-MyOcean $^{7}$ product).

\subsection{Statistical Analysis}

This section describes the method used to calculate the trend and climatology (Figure 2 left panel) from oceancolour data. For each grid point a yearly time series of summer mean Chl-a concentration was calculated for the period of 1998-2009 (12 points maximum, some summer values can be missing at some grid points if not enough values where available to calculate the summer mean).

To calculate summer values the monthly mean was calculated and the summer values were computed. A threshold on the minimum number of days required to create a valid monthly value was fixed at the level of 10 days and a threshold on the minimum number of years required to create a valid time-series was fixed at the level of 9 years.

Trend values $\left.\left(\left(\mathrm{mg} \cdot \mathrm{m}^{-3}\right) \cdot \mathrm{yr}^{-1}\right)\right)$ are estimated using Sen's slope method [32-34] for each grid point Chl-a time series.

For each grid point Sen's method calculates the slope of all data value pairs:

$$
Q_{m}=\frac{X_{i}-X_{j}}{i-j}, \text { for all } i \text { and } j \text { where } i>j
$$

where:

- $X_{i}$ and $X_{j}$ are the summer mean Chl-a concentration for years $i$ and $j$;

- $Q_{m}$ is the linear slope between $X_{i}$ and $X_{j}$ summer values;

- $m$ is the index of slope estimates.

\footnotetext{
${ }^{3}$ Summer is defined as the months from June to September for stations north of 59 degrees in the Baltic Sea (Gulf of Bothnia and Gulf of Finland) and from May to September for all other stations.

${ }^{4}$ In each figure of the paper the Sea of Azov has been masked because it is very shallow (maximum 15 metres depth) and ocean-colour products would be strongly affected by bottom reflectance; the White Sea has been masked because it was out of our domain of interest.

${ }^{5}$ The Global Ocean GSM-MyOcean product is described in Section 2.1.1.

${ }^{6} \mathrm{Chl}-\mathrm{a}$ areas are defined in Section 2.5.

${ }^{7}$ The Med Regional SeaWiFS RAN-MyOcean dataset is described in Section 2.1.1.
} 


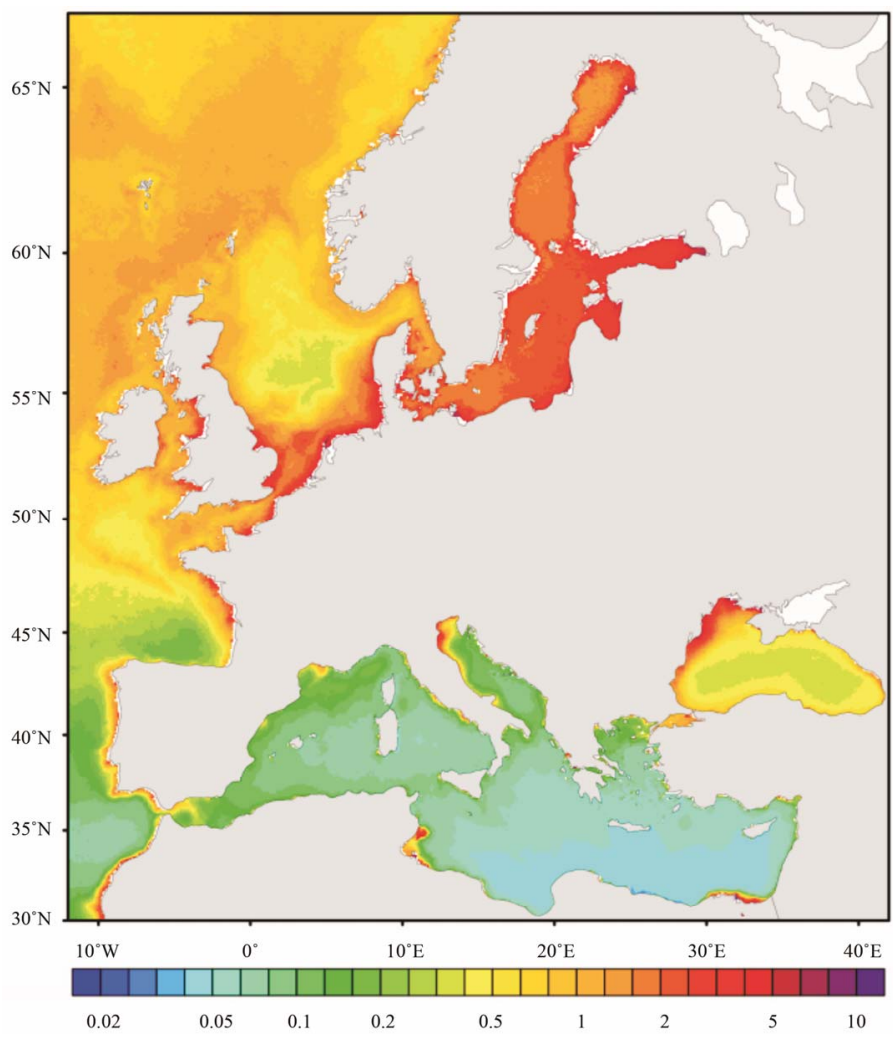

(a)

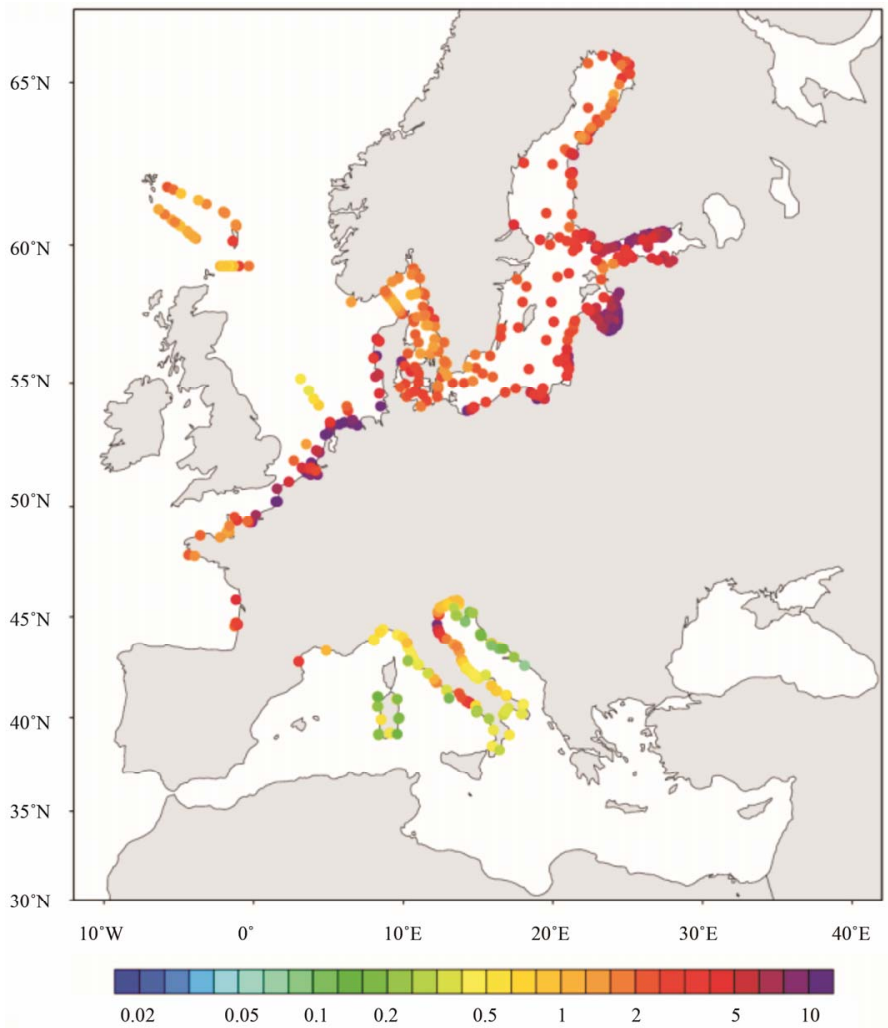

(b)

Figure 2. Summer (May-Sept.) mean Chl-a concentration in European seas for the period of 1998-2009 from the MyOcean ocean-colour global dataset (a) and the Eionet in-situ dataset (b). 


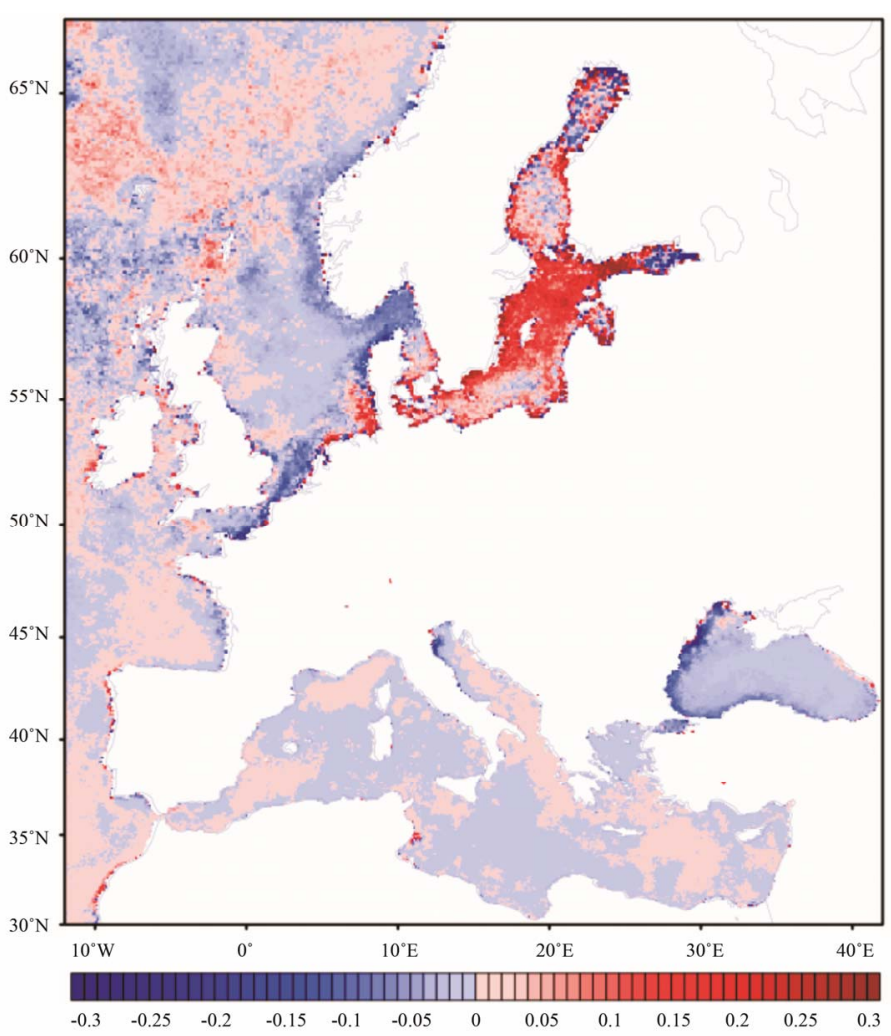

(a)

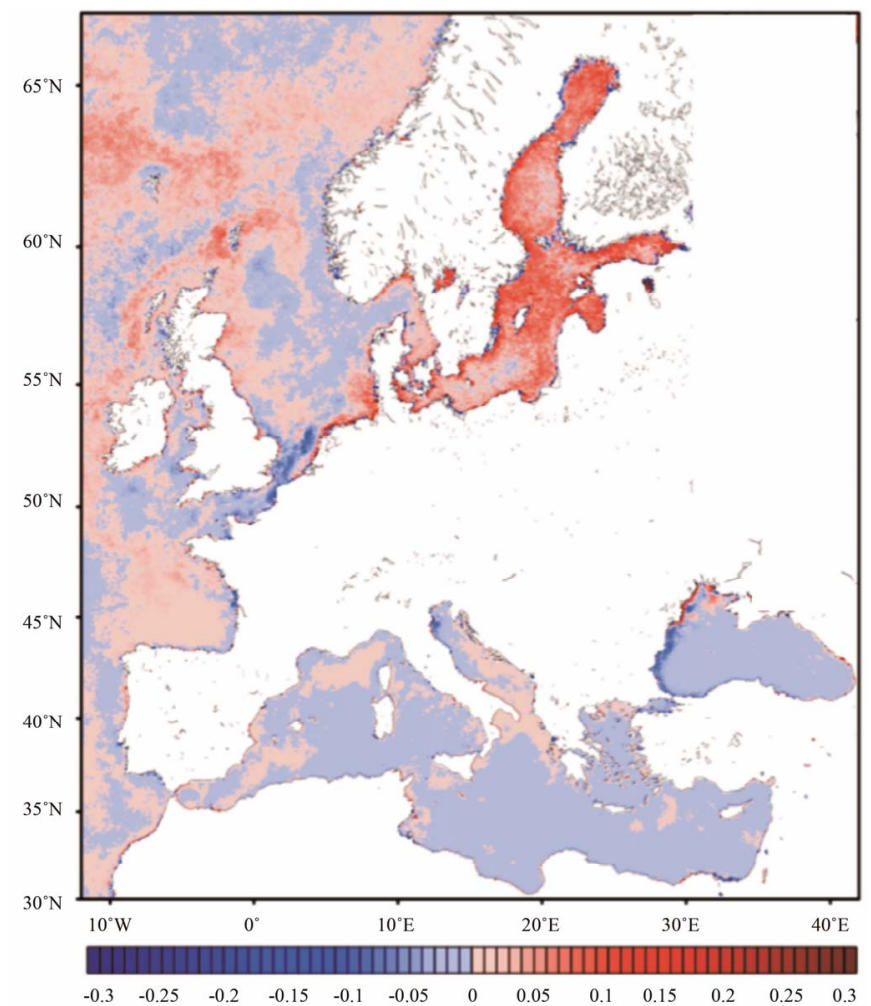

(b)

Figure 3. Pan-European Chl-a trend values $\left(\mathrm{mg}^{\circ} \mathrm{m}^{-3} \cdot \mathrm{y}^{-1}\right)$ (Sen's slope) from Global Ocean SeaWiFS RAN-MyOcean (a) and from Global Ocean GSM-MyOcean (b) for the period of 1998-2009. Both significant and non-significant trends were displayed. 
If there are $n$ summer values $X_{i}$ in the time series we get as many as $M=\frac{n *(n-1)}{2}$ slope estimates $Q_{m}$ and $m=1 \cdots M$.

Sen's estimator of slope is the median of these $M$ values of $Q$. For each grid point the $M$ values of $Q$ are ranked from the smallest to the largest and Sen's estimator is:

$$
\text { SLOPE }=Q_{[(M+1) / 2]} \text { if } M \text { is odd; }
$$

$$
\mathrm{SLOPE}=\left(Q_{[M / 2]}+Q_{[(M+2) / 2]}\right) / 2 \text { if } M \text { is even; }
$$

Ocean colour Chl-a and in situ trends were calculated with this method (Figures 3 and $\mathbf{4}$ ).

A Mann-Kendal statistics check [16,17] is applied to each Chl-a grid point to identify the statistically significant trends values at a $95 \%$ confidence level.

Chl-a standard deviation (STD) values were calculated using a non-parametric approach $(68 \%$ confidence interval is considered as $2 \sigma$ ). Non-parametric Sen's slope [15-17] is normalized by the non-parametric Chl-a STD values of each grid point, so that $\mathrm{CSIO} 23(+)$ is then calculated as:

$$
\operatorname{CSI} 023(+)=\frac{\text { SLOPE }}{\text { STD }}
$$

Once CSI023(+) values have been calculated at each ocean-colour data grid point they are presented in two different ways:

1) In a map over the European seas for values above the $95 \%$ confidence level (Figure 5(a)).
2) Histograms of percentages of positive, negative and not significant values of CSIO23(+) in the Mediterranean Chl-a areas (Figures 6(a)-(f)).

\subsection{Chl-a Areas Description}

In the Mediterranean Sea, where a regional ocean-colour product at high spatial resolution was available, a special application of CSI023(+) was performed for the period of 1998-2009. This application uses the concept of "Chl-a areas", defined on the basis of river basins and political borders, where Chl-a trends are calculated. This method utilizes the high spatial resolution of the colour images and thus produces a more robust trend estimate than the pan-European trend indicator.

Chl-a areas were defined in the Mediterranean (68 Chl-a areas), using information on the River Basin Districts (RBDs), and political borders when RBDs were not defined. Moreover, 18 open-ocean sub-basins ${ }^{8}$ were identified in the Mediterranean and used to design the Chl-a areas. Within each Chl-a area two sub-areas are defined: a coastal one (IN), from the coast to a depth of 30 metres and an offshore one (OFF), from a depth of 30 to 200 metres. A name composed of 3 parts was associated with each single Chl-a area as following: 1) name of the RBD or name of the country; 2) name of the sub-basin; 3) "IN" if it is the inshore part of the Chl-a area or "OFF" if it is the offshore part of the Chl-a area.

For example, the offshore part of the Maltese Chl-a area in the Strait of Sicily will be named "Malta-SSIOFF". In Annex 1 we present details of Chl-a areas with a table listing their names.

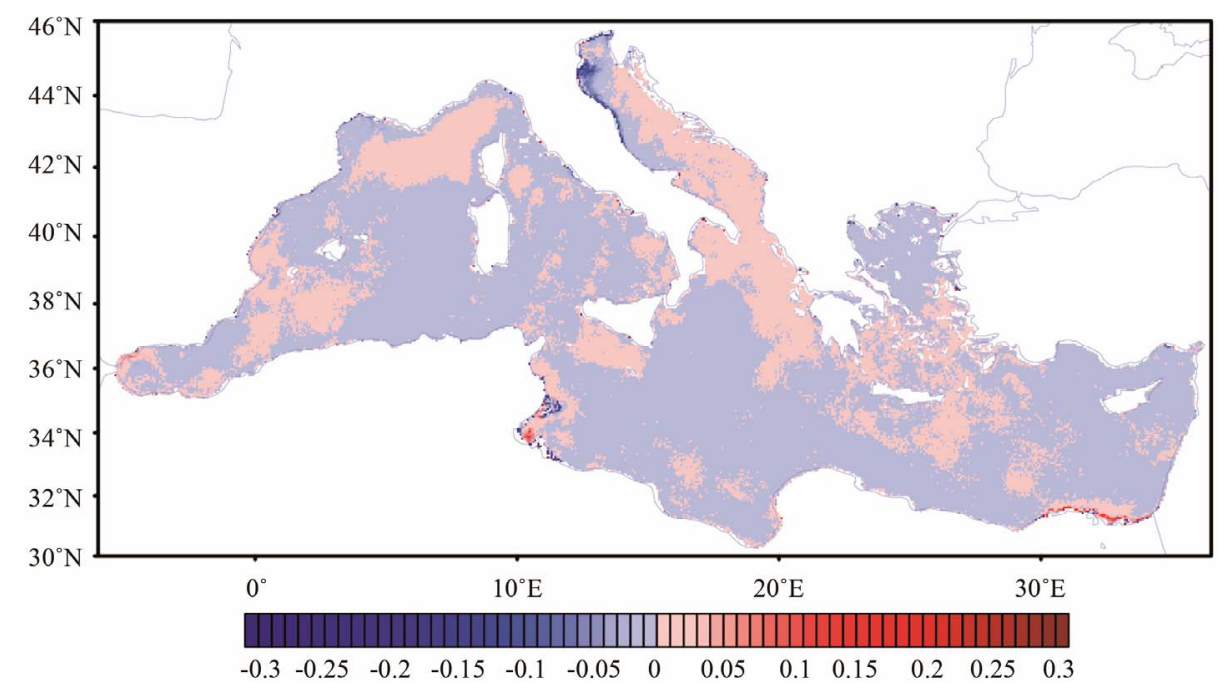

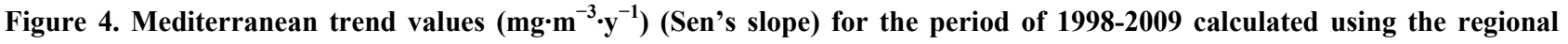
product Med Regional SeaWiFS RAN-MyOcean. Both significant and non-significant trends are displayed.

${ }^{8}$ North Adriatic Sea (NAD), South Adriatic Sea (SAD), Algerian Sea (ALG), Alboran Sea (ALS), Algero-Provençal Basin (APB), Gulf of Gabès (GGA), Gulf of Lion (GLI), Iberian Sea (Balearic Sea) (IBS), North Ionian Sea (NIO), South Ionian Sea (SIO), North Levantine Basin (NLB), South Levantine Basin (SLB), Ligurian Sea (LGS), Strait of Sicily (SSI), North Tyrrhenian Sea (NTY), South Tyrrhenian Sea (STY). 


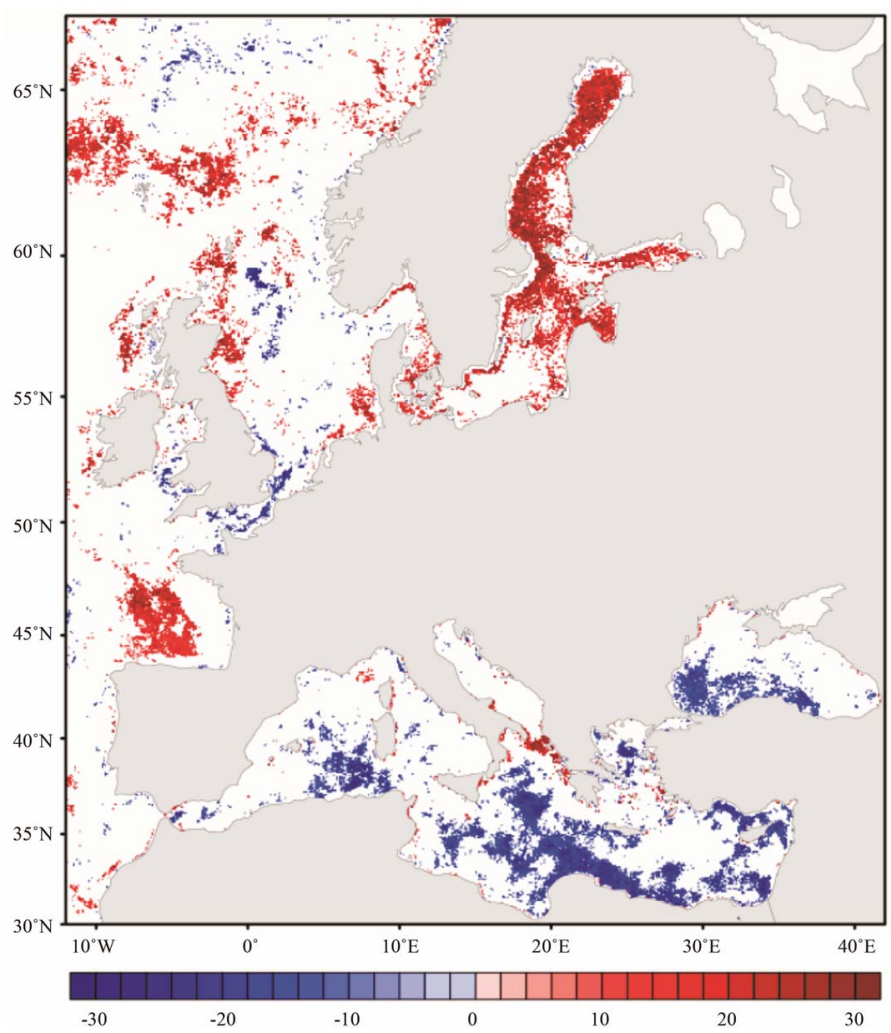

(a)

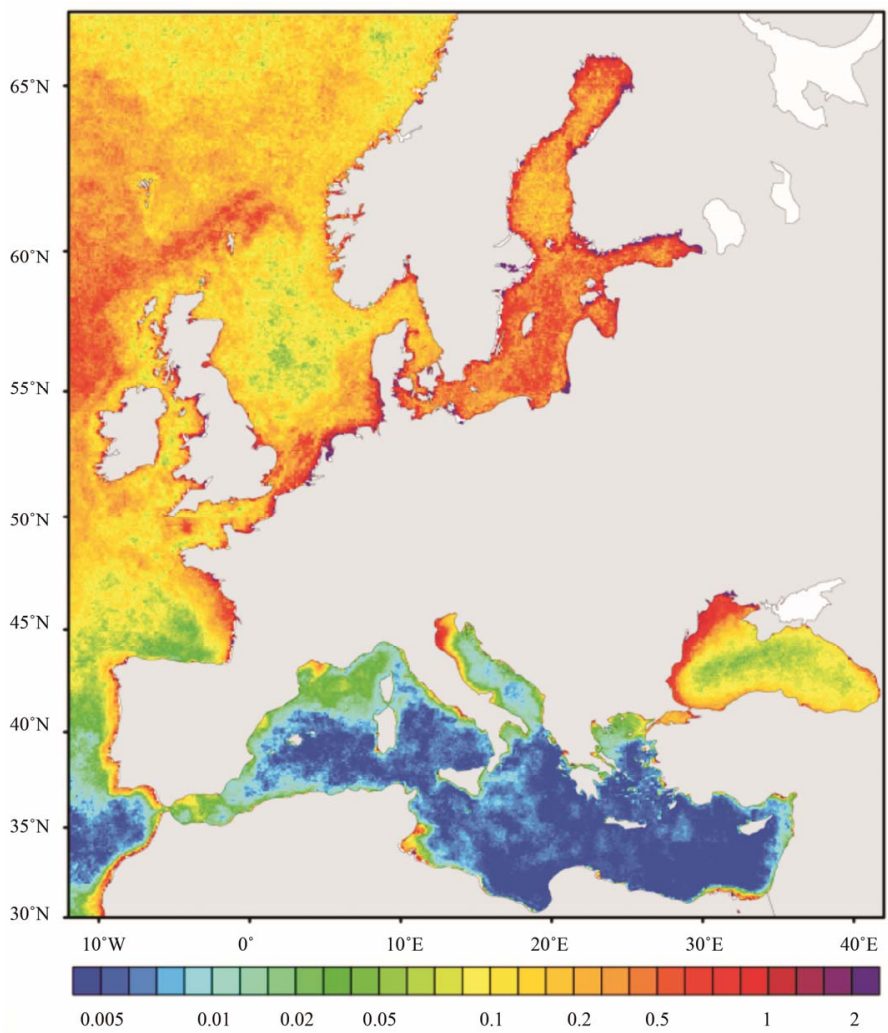

(b)

Figure 5. CSI023(+) pan-European trend indicator values $\left(\mathrm{mg} \cdot \mathrm{m}^{-3}\left(\mathrm{mg}^{-} \mathrm{m}^{-3}\right)^{-1} \cdot \mathrm{y}^{-1}\right)$ (a) for the period of 1998-2009. White areas indicate values that are statistically not significant. Chl-a standard deviation $\left(\mathrm{mg}^{-3} \mathrm{~m}^{-3}\right)(\mathrm{b})$ for the period of $1998-2009$. 


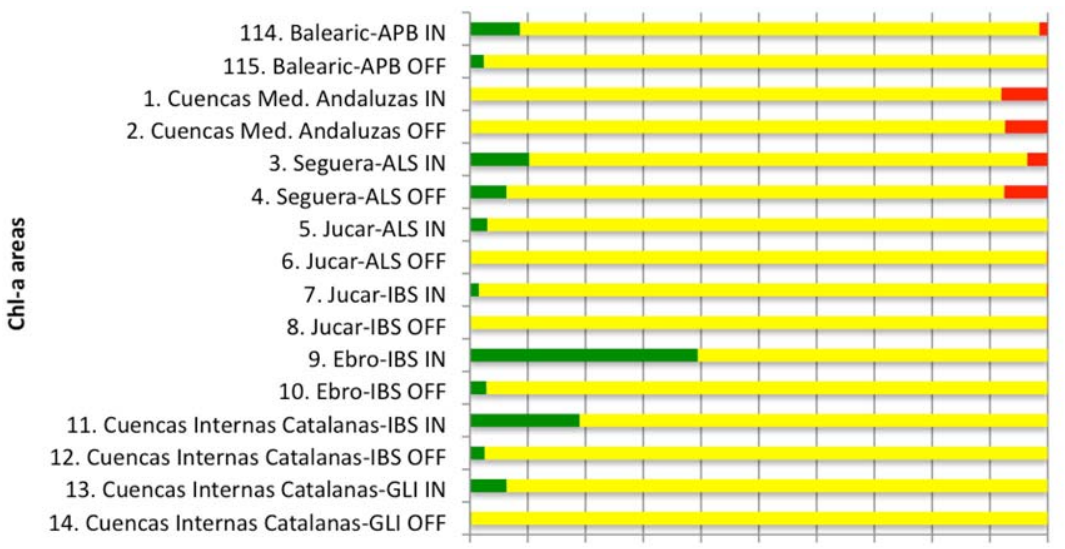

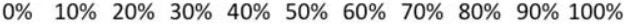

Decreasing No Trend Increasing

(a)

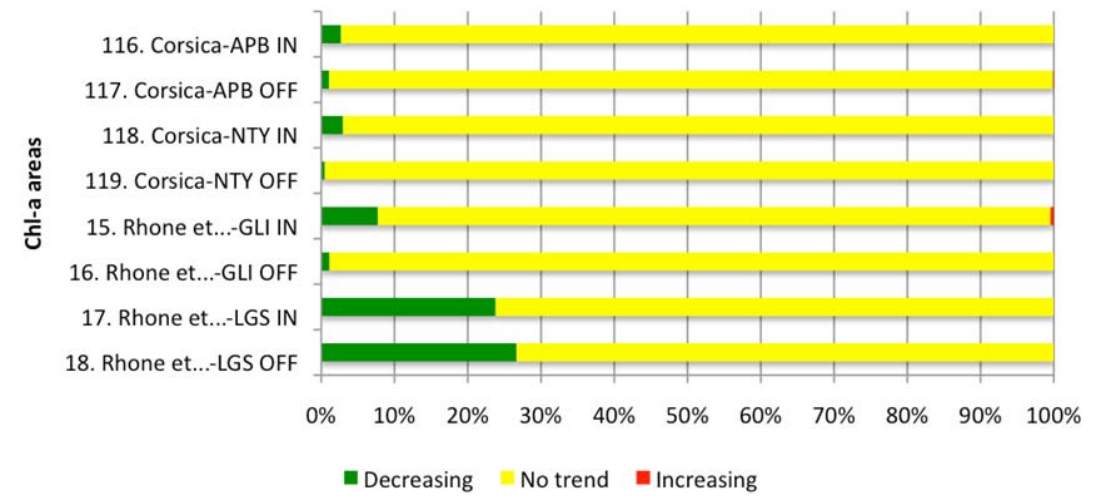

(b)

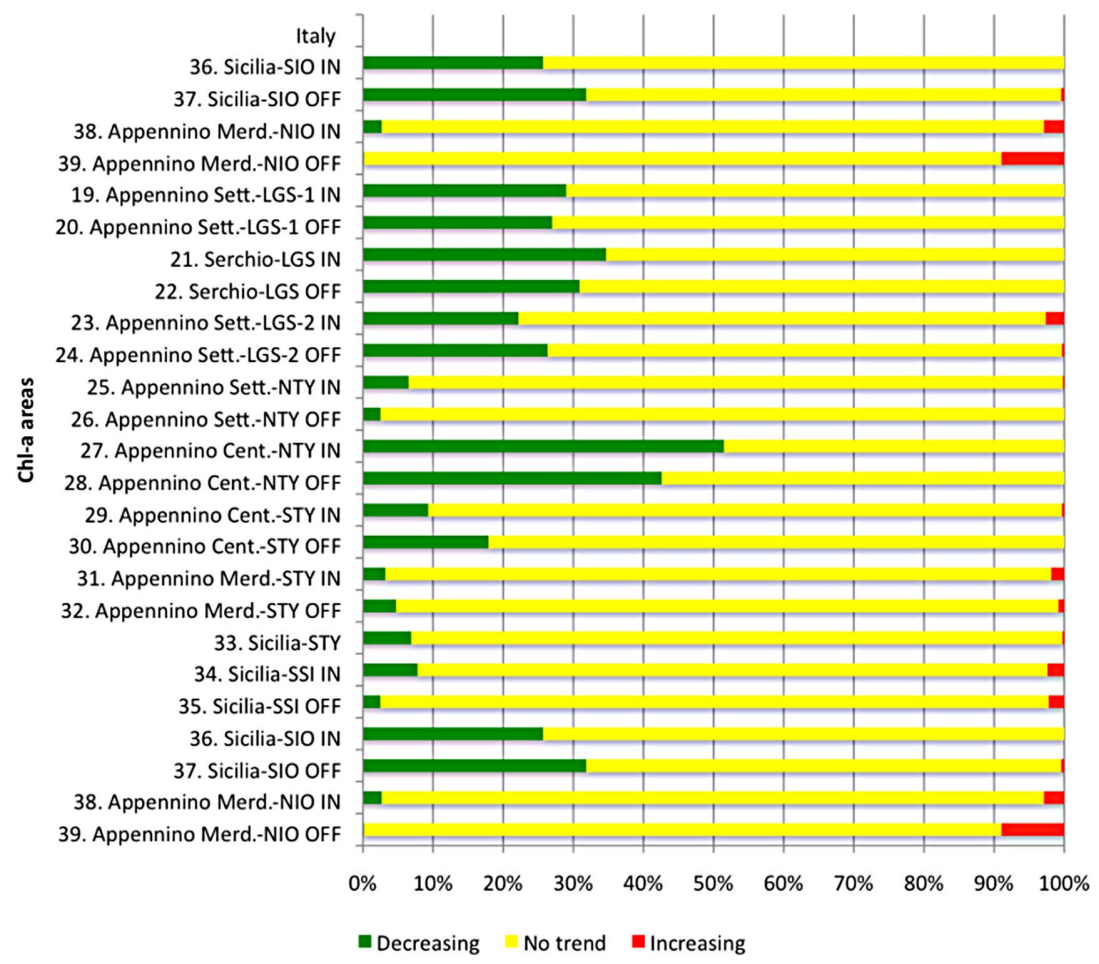

(c) 


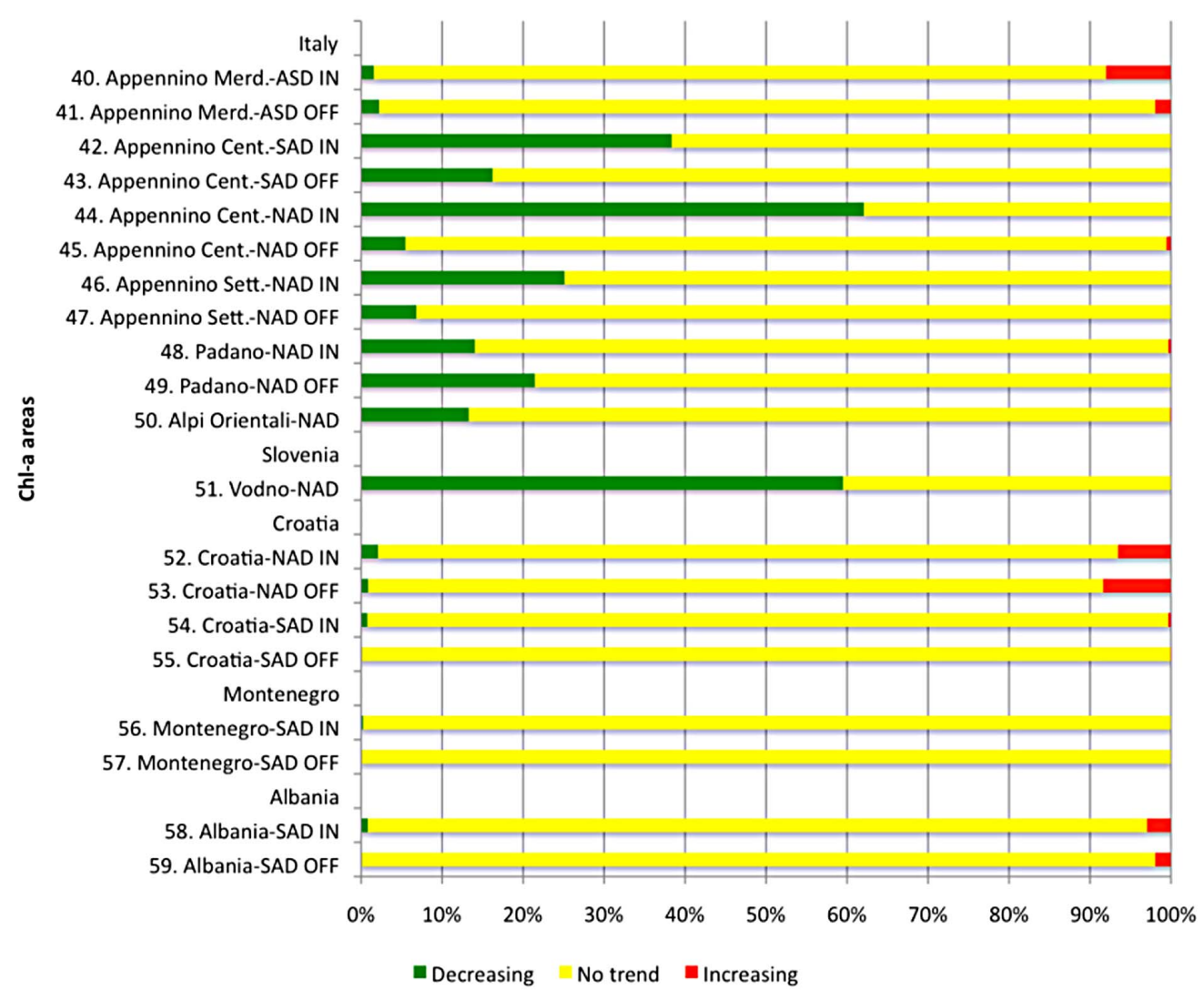

(d)

60. Epirus-1-NIO IN 61. Epirus-1-NIO OFF 62. Western Sterea Ellada-NIO IN 63. Western Sterea Ellada-NIO OFF 64. Nothern Peloponnese-SIO IN 65. Nothern Peloponnese-SIO OFF 66. Western Peloponnese-SIO IN 67. Western Peloponnese-SIO OFF 68. Western Peloponnese-AEG IN 69. Western Peloponnese-AEG OFF

70. Eastern Peloponnese-AEG IN 71. Eastern Peloponnese-AEG OFF

72. Nothern Peloponnese-AEG IN 73. Nothern Peloponnese-AEG OFF

74. Eastern Sterea Ellada-NIO IN

75. Eastern Sterea Ellada-NIO OFF 76. Attica-AEG IN 77. Attica-AEG OFF 78. Eastern Sterea Ellada-AEG IN 79. Eastern Sterea Ellada-AEG OFF 80. Western Macedonia IN 81. Western Macedonia OFF

82. Central Macedonia-AEG IN

83. Central Macedonia-AEG OFF

84. Eastern Macedonia IN 85. Eastern Macedonia OFF

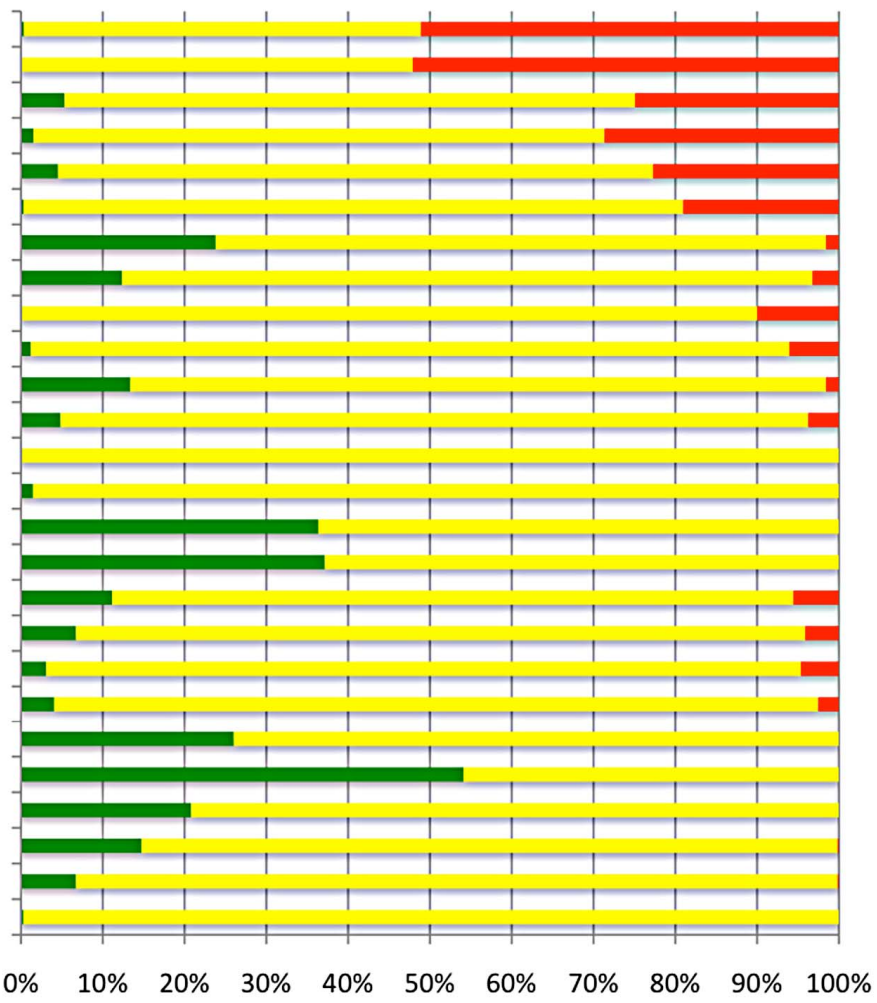

घ "Decreasing" $\quad$ No trend "Increasing"

(e) 


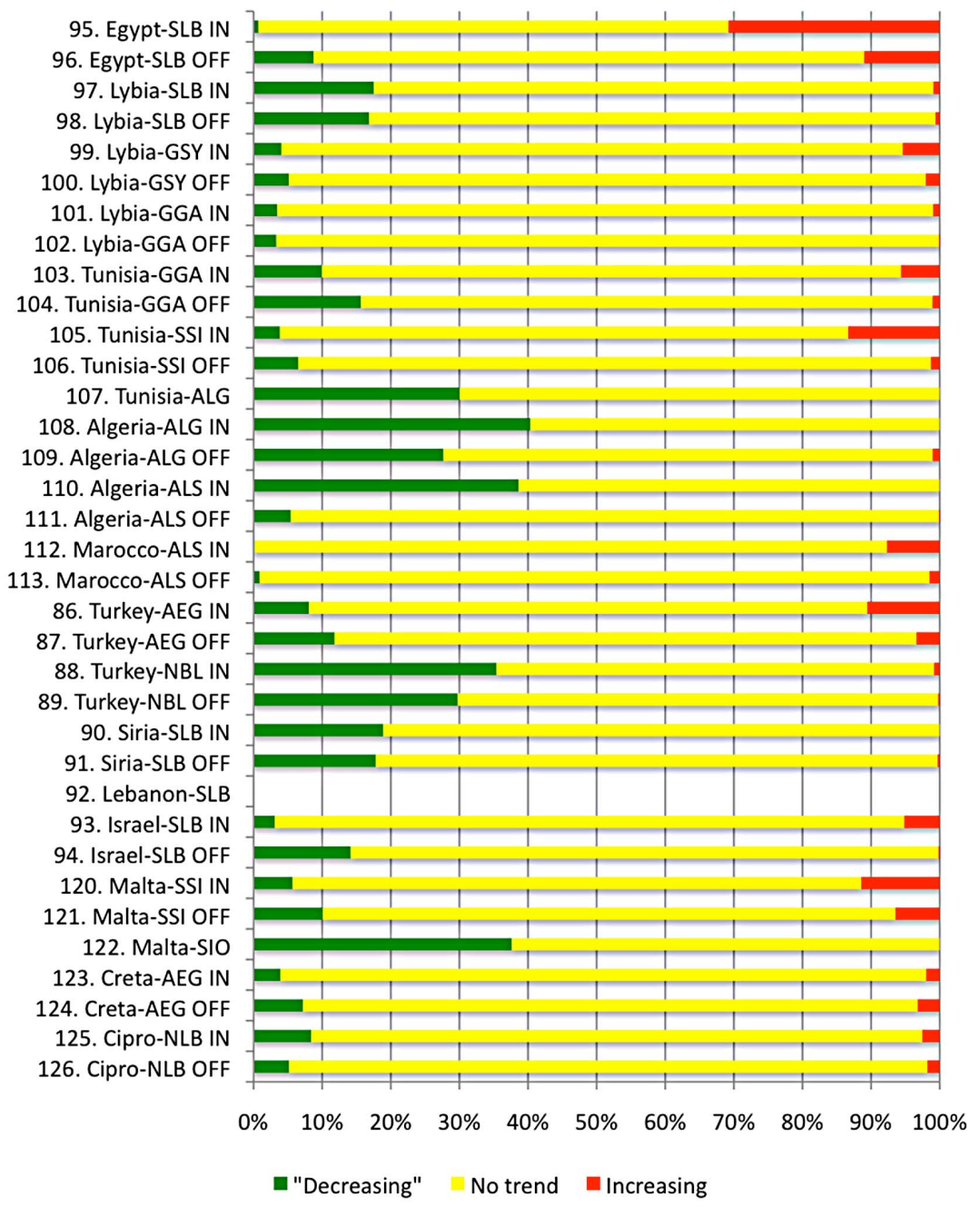

(f)

Figures 6. (a) and (b) CSI023(+) Chl-a area trend indicators in the Western Mediterranean Spanish Coast (a) and Ligurian Sea, Gulf of Lions, Tyrrhenian Sea and Algero Provencal Basin (b) for the period of 1998-2009. For each Chl-a area the red bars indicate the percentage of grid points with significant increasing trends, the green bars indicate the percentage of grid points with decreasing significant trends and the yellow bars indicate the percentage of grid points without significant trend; (c) and (d) CSI023(+) Chl-a area trend indicators in the Ligurian, Tyrrhenian, Ionian Sea and Sicily Strait (c) and in the Adriatic Sea (d) for the period of 1998-2009. For each Chl-a area the red bars indicate the percentage of grid points with significant increasing trends, the green bars indicate the percentage of grid points with decreasing significant trends and the yellow bars indicate the percentage of grid points without significant trend; (e) and (f) CSI023(+) Chl-a area trend indicators in the Aegean Sea and Greek coasts (e) and in the Eastern Mediterranean and African Coasts (f) for the period of 1998-2009. For each Chl-a area the red bars indicate the percentage of grid points with significant increasing trends, the green bars indicate the percentage of grid points with decreasing significant trends and the yellow bars indicate the percentage of grid points without significant trend.

\section{Validation against in-Situ Data}

The validation of the ocean-colour products used to calculate CSI023(+) consists of the comparison of the oceancolour products with in-situ values from the EEA-Eionet databank.

In-situ Eionet observations are re-gridded on the satellite products spatial grids $\left(1 / 24^{\circ}\right.$ when using the Global Ocean GSM-My-Ocean and $1 \mathrm{~km} \times 1 \mathrm{~km}$ when using Med Regional SeaWiFS RAN-MyOcean).
In the comparison between Global Ocean GSM-MyOcean and in-situ data we proceeded as follows: for each in-situ data of a specific day we check if there is a corresponding satellite daily data for that day. Then we build a datasets of daily match-up in-situ and satellite data. Finally, summer and annual mean values are calculated by averaging all the corresponding (same day) in-situ and satellite data for that summer and year respectively. Summer and yearly mean satellite values are then compared with the corresponding in-situ values. 
In the case of the Med Regional SeaWiFS RANMyOcean and in-situ data comparison we enlarged the area for searching the corresponding satellite and in-situ data due to the lower coverage of the regional product than the global merged product and the spatial resolution is higher decreasing the chance of finding corresponding in-situ and satellite data. In order to perform the comparison we searched in a surrounding area of 4 grid points around each single in-situ observation. Then we build a datasets of daily match-up in-situ and satellite data. Finally summer and annual mean values were calculated by averaging all the corresponding daily in-situ and satellite data for that summer and year respectively. Summer and yearly mean satellite values were then compared with the corresponding in-situ values.

The MedOC4 algorithm was tested and validated up to value of $10 \mathrm{mg} \cdot \mathrm{m}^{-3}$ of Chl-a and no higher value was present in the satellite dataset. Therefore we removed from the comparison the in-situ Chl-a data higher than this value.

The number of corresponding in-situ and ocean-colour daily values for the different satellite products is reported in Table 3.

The number of corresponding summer and annual mean values used in the comparison were reported in Table 3 together with the validation results.

We did not compare Global Ocean SeaWiFS RANMyOcean, because only monthly ocean-colour values were available.

Global Ocean GSM-MyOcean product validation results were presented in Figures 7 to 10, while Med Regional SeaWiFS RAN-MyOcean product validation was presented in Figure 10. The correlations were performed taking the logarithm on a decimal basis of the
Chl-a values. The validation results were presented in Table 3.

The correlation between in-situ data and Global Ocean GSM-MyOcean ocean colour Chl-a concentration was relatively high $\left(\mathrm{r}^{2}=0.53\right)$ when analysis was carried out using all the data covering the entire European seas domain (Figure 7), although bias is equal to $1.10\left(\mathrm{mg} \cdot \mathrm{m}^{-3}\right)$ and RMSD is $4.46\left(\mathrm{mg} \cdot \mathrm{m}^{-3}\right)$. At the basin scales correlation values are lower, for the Mediterranean (Figure 8) $\mathrm{r}^{2}$ is equal to 0.31 in the summer analysis $(0.34$ in the annual analysis) with a low bias $\left(0.36\left(\mathrm{mg} \cdot \mathrm{m}^{-3}\right)\right)$ and RMSD is equal to $1.95\left(\mathrm{mg} \cdot \mathrm{m}^{-3}\right)$. In the annual analysis the Mediterranean bias and RMSD increase to $0.42\left(\mathrm{mg} \cdot \mathrm{m}^{-3}\right)$ and $2.15\left(\mathrm{mg} \cdot \mathrm{m}^{-3}\right)$ respectively. In the Black Sea (Figure 8) we register the minimum number of data availability (46 for the full year and 23 for the summer period) and results showed that $r^{2}=0.39$ in the annual analysis and $r^{2}$ $=0.38$ in the summer analysis. Bias is equal to -0.62 $\left(\mathrm{mg} \cdot \mathrm{m}^{-3}\right)$ in the summer analysis indicating an overestimation of the in-situ data by the satellite ones, while RMSD is equal to $1.00\left(\mathrm{mg} \cdot \mathrm{m}^{-3}\right)$. In the annual analysis of Black Sea data Bias is positive and equal to 0.41 $\left(\mathrm{mg} \cdot \mathrm{m}^{-3}\right)$, while RMSD is equal to $1.86\left(\mathrm{mg} \cdot \mathrm{m}^{-3}\right)$. The North-east Atlantic (Figure 9) shows relative high $\mathrm{r}^{2}=$ 0.45 in summer and $r^{2}=0.46$ in the yearly analysis. Consequently, the Bias is low in the annual analysis $\left(0.02\left(\mathrm{mg} \cdot \mathrm{m}^{-3}\right)\right)$ and in the summer period $0.23\left(\mathrm{mg} \cdot \mathrm{m}^{-3}\right)$. Thus, RMSD for the North-east Atlantic is 1.43 in the annual analysis and 1.44 in the summer analysis. While in the North Sea (Figure 9) we found $r^{2}$ values similar to the other basins ( 0.40 in the annual analysis and 0.33 in the summer period analysis) showing that the higher Bias RMSD equal to $2.12\left(\mathrm{mg} \cdot \mathrm{m}^{-3}\right)$ in the annual analysis $\left(2.03\left(\mathrm{mg} \cdot \mathrm{m}^{-3}\right)\right.$ in the summer analysis) and RMSD is

Table 3. Validation of the ocean-colour data products used in the calculation of CSI023(+) .

\begin{tabular}{|c|c|c|c|c|c|c|}
\hline Seas and Period of Analysis & $r^{2}$ & Slope & Intercept & BIAS & RMSD & Num. of Points \\
\hline European Seas Annual & 0.53 & 0.74 & -0.13 & 1.10 & 4.46 & 4176 \\
\hline European Seas Summer & 0.54 & 0.78 & -0.17 & 1.01 & 4.12 & 3107 \\
\hline Baltic Sea Annual & 0.02 & 0.41 & 0.15 & 1.55 & 5.10 & 1264 \\
\hline Baltic Sea Summer & 0.15 & 0.43 & 0.14 & 1.26 & 4.74 & 1103 \\
\hline Mediterranean Sea Annual (GSM) & 0.34 & 0.61 & -0.29 & 0.42 & 2.15 & 1570 \\
\hline Mediterranean Sea Summer (GSM) & 0.31 & 0.58 & -0.41 & 0.36 & 1.95 & 1133 \\
\hline North Sea Summer & 0.33 & 0.55 & -0.08 & 2.03 & 5.99 & 637 \\
\hline North-East Atlantic Annual & 0.46 & 0.76 & -0.05 & 0.02 & 1.43 & 378 \\
\hline North-East Atlantic Summer & 0.45 & 0.59 & -0.01 & 0.23 & 1.44 & 211 \\
\hline Black Sea Annual & 0.39 & 0.61 & -0.06 & 0.41 & 1.86 & 46 \\
\hline Black Sea Summer & 0.38 & 0.87 & 0.25 & -0.62 & 1.00 & 23 \\
\hline Mediterranean Sea Summer (Med Regional) & 0.41 & 0.55 & -0.22 & -0.04 & 1.44 & 1285 \\
\hline
\end{tabular}

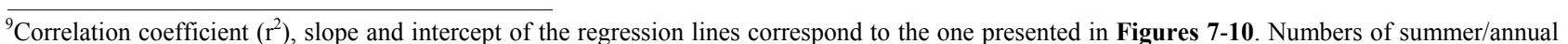
mean values compared are reported in the table for each of the seas and European Sea and for each of the aggregation period (summer or year). Root Mean Square Distance (RMSD) and BIAS are calculated for Chl-a absolute values $\left(\mathrm{mg} \cdot \mathrm{m}^{3}\right)$, not logarithmic. The Mediterranean Sea results are reported for the Global Ocean GSM-MyOcean product (GSM) and Med Regional SeaWiFS RAN-MyOcean product (Med Reg). 


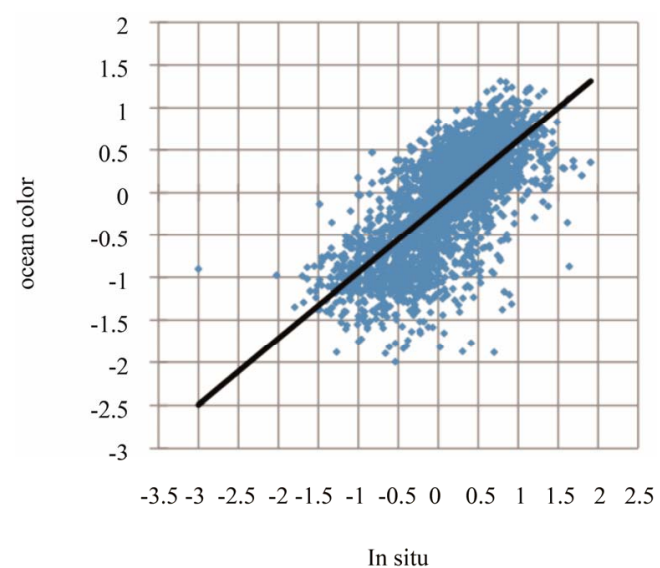

Figure 7. Summer Chl-a in-situ concentration and the ocean-colour Global Ocean GSM-MyOcean Chl-a concentration for all selected stations in the European seas $(\log 10$ $\left.\mathrm{mg} \cdot \mathrm{m}^{-3}\right)$. The black line is the best linear approximation between ocean colour $(y)$ and in-situ values $(x)$.

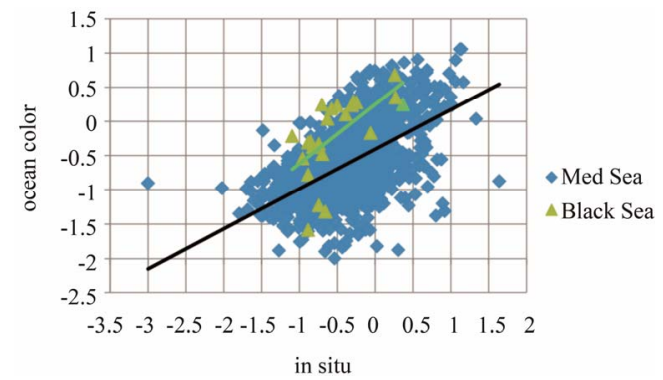

Figure 8. Summer Chl-a in-situ concentration and the ocean-colour Global Ocean GSM-MyOcean Chl-a concentration for all selected stations in the Mediterranean Sea $\left(\log 10 \mathrm{mg} \cdot \mathrm{m}^{-3}\right)$. The black line is the best linear approximation between ocean colour $(y)$ and in-situ values $(x)$ in the Mediterranean Sea and the green line is the one for the Black Sea.

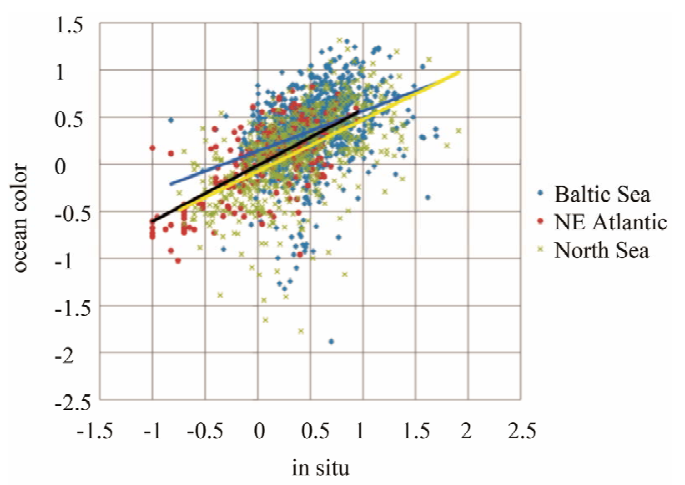

Figure 9. Summer Chl-a in-situ concentration and the ocean-colour Global Ocean GSM-MyOcean Chl-a concentration $\left(\log 10 \mathrm{mg} \cdot \mathrm{m}^{-3}\right)$ for all selected stations in the Baltic Sea (blue diamond), North-east Atlantic (orange circle) and North Sea (green cross). The best linear approximation between ocean colour $(y)$ and in-situ values $(x)$ is in blue for the Baltic Sea, black for the North-east Atlantic and yellow for the North Sea.

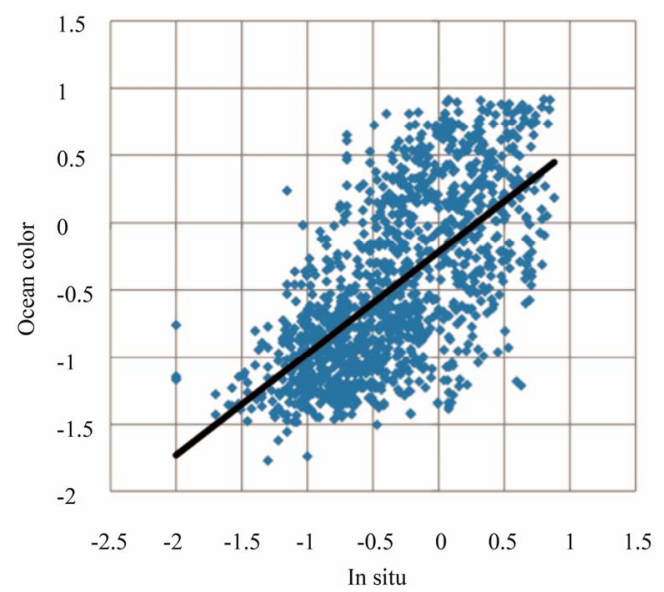

Figure 10. Summer $\log 10$ Chl-a in-situ concentration ( $x$ axis) compared with the ocean-colour Med Regional SeaWiFS RAN-MyOcean $\log 10$ Chl-a concentration (y axis). Log10 Chl-a values were expressed in $\mathrm{mg} \cdot \mathrm{m}^{-3}$. The black line is the best linear approximation between ocean colour (y) and in-situ values (x).

equals to $6.80\left(\mathrm{mg} \cdot \mathrm{m}^{-3}\right)$ in the annual analysis $(5.99$ $\left(\mathrm{mg} \cdot \mathrm{m}^{-3}\right)$ in the summer analysis). The Baltic Sea (Figure 9) the correlation noticeably drops $\left(\mathrm{r}^{2}\right.$ equal to 0.02 in the annual analysis and 0.15 in the summer analysis) and Bias is equals to $1.55\left(\mathrm{mg} \cdot \mathrm{m}^{-3}\right)$ in the annual analysis and $1.26\left(\mathrm{mg} \cdot \mathrm{m}^{-3}\right)$ in the summer analysis, while RMSD is equal to $5.10\left(\mathrm{mg} \cdot \mathrm{m}^{-3}\right)$ in the annual analysis and 4.74 $\left(\mathrm{mg} \cdot \mathrm{m}^{-3}\right)$ in the summer analysis.

The comparison of Med Regional SeaWiFS RANMyOcean with in-situ data in the Mediterranean Sea shows a correlation $\mathrm{r}^{2}=0.41$ in summer analysis (Table 3 and Figure 10) and 0.36 in the yearly analysis, which are higher than that observed with the Global Ocean GSM-MyOcean data (Figure 8 and Table 3; $\mathrm{r}^{2}=0.31$ for the summer analysis and 0.34 for the yearly analysis). Bias of the Mediterranean regional products $(-0.04$ $\left(\mathrm{mg} \cdot \mathrm{m}^{-3}\right)$ in the summer analysis and $0.15\left(\mathrm{mg} \cdot \mathrm{m}^{-3}\right)$ in the yearly analysis) and RMSD $\left(1.44\left(\mathrm{mg} \cdot \mathrm{m}^{-3}\right)\right.$ in the summer analysis and $1.36\left(\mathrm{mg} \cdot \mathrm{m}^{-3}\right)$ in the yearly analysis) are lower than that of the Global product.

In addition to the comparison of in Chl-a concentrations presented above we also propose a comparison of in-situ and satellite trends. To perform this comparison we identified locations at which there were at least 9 summer Chl-a mean values of corresponding in-situ and satellite data. The identified time series are 48 in the Global Ocean GSM-MyOcean and in-situ trends comparison. The results of this comparison were presented in a scatter plot in Figure 11 and in a map in Figure 12.

Results show that there are 16 locations in which both satellite and in-situ products detect positive trends, 17 locations in which both satellite and in-situ products detected negative trends, 6 locations in which in-situ products detected positive trends while satellite products 


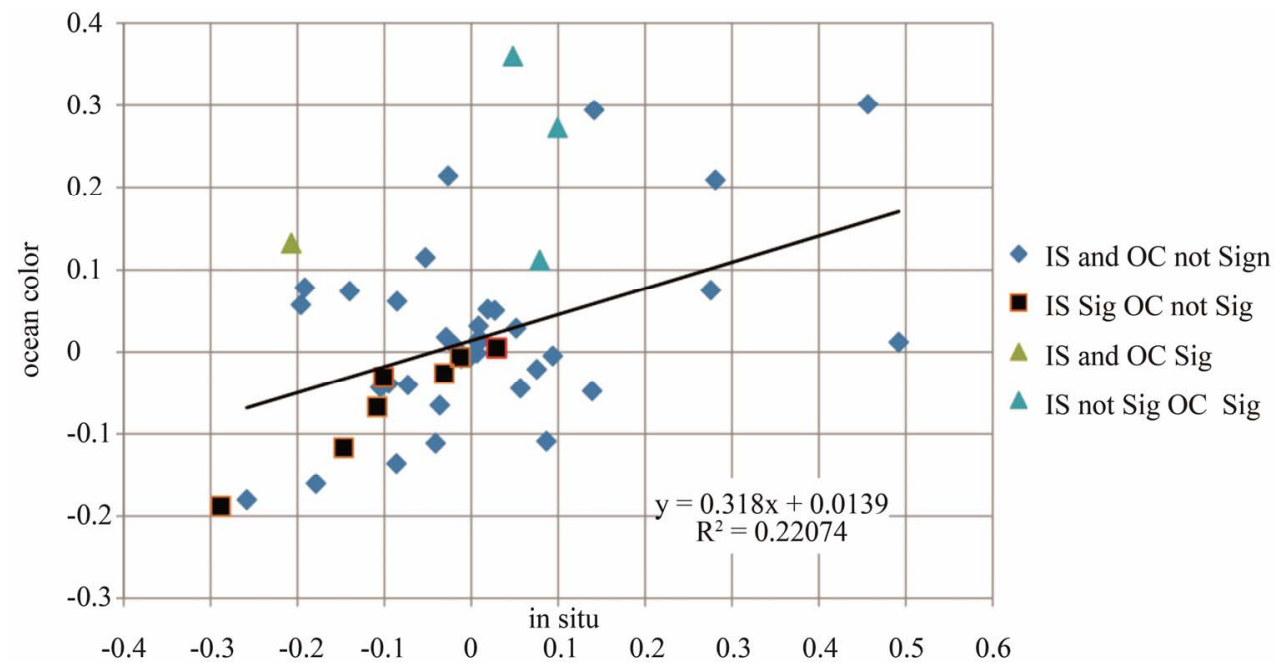

Figure 11. Summer Chl-a in-situ trends and the ocean-colour Global Ocean GSM-MyOcean Chl-a trends for all selected stations in the European Seas $\left(\mathrm{mg} \cdot \mathrm{m}^{-3} \cdot \mathrm{y}^{-1}\right)$. The black line is the best linear approximation between ocean colour $(\mathrm{y})$ trends and in-situ trend values (x). The significance of the trends is was presented with different symbols: In-situ (IS) and Ocean Colour (OC) not significant-blue diamond; IS significant $(95 \%)$ and OC not significant-Black square; IS and OC both significant (95\%) green triangle; IS not significant and OC significant (95\%) blue triangle.

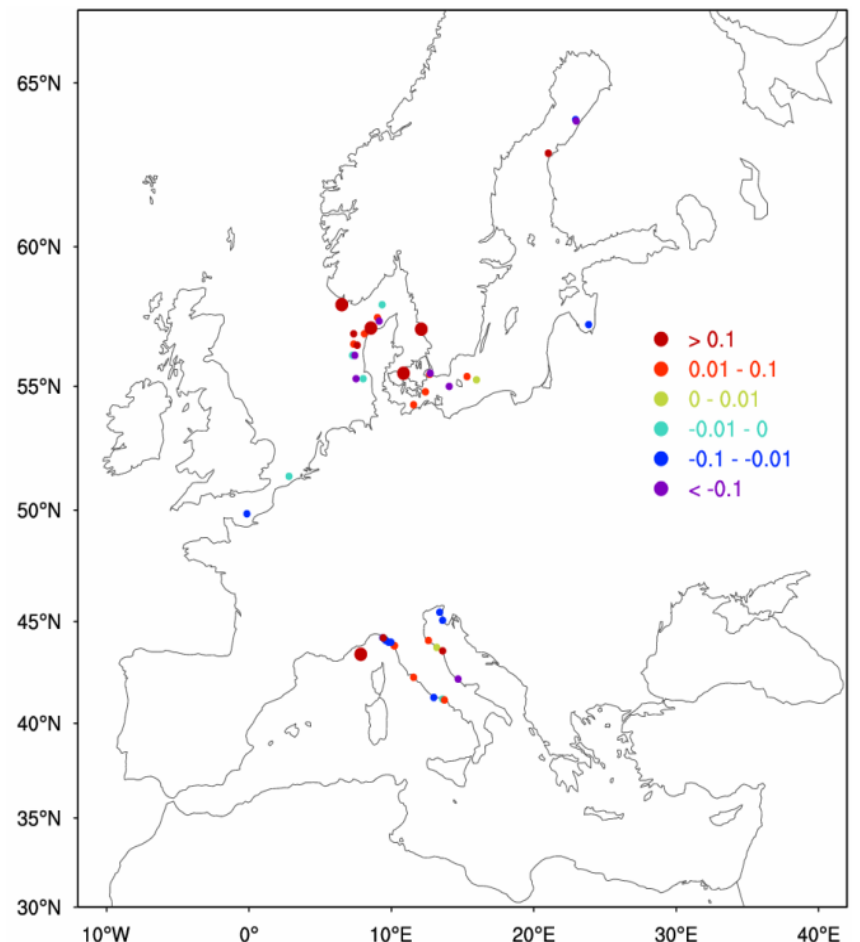

(a)

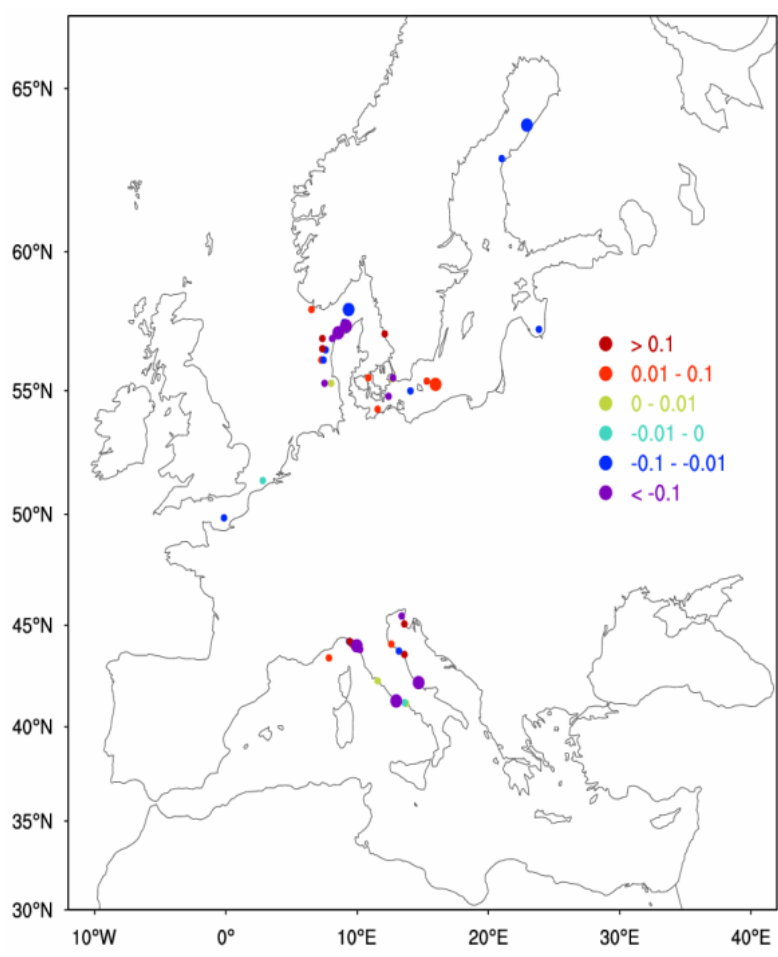

(b)

Figure 12. Comparison of Chl-a trends calculated estimated from ocean colour data Global Ocean GSM-MyOcean in the European seas (a) for the period of $1998-2009\left(\mathrm{mg} \cdot \mathrm{m}^{-3} \cdot \mathrm{y}^{-1}\right)$ and from the in-situ dataset (b). Large circles correspond to significant $(95 \%$ confidence level) trends while small circles correspond to non-significant trends. The palette indicates different trend's range $\left(\mathrm{mg} \cdot \mathrm{m}^{-3}\right)$ with different colours.

detect negative trends and 9 locations in which in-situ products detected negative trends while satellite products detected positive trends. Position of the locations where trends were identified was shown in Figure 12 together with the trend slope and significance level.

The satellite and in-situ Chl-a trends comparison were not performed at the level of Mediterranean Chl-a areas because only few corresponding time series were detect- 
able and cannot represent the different Chl-a areas.

\section{Results and Discussion}

Ocean colour Chl-a concentrations and trends were compared with in-situ ones. Paragraph 4.1 presents the results of this comparison. The mean summer (May-September) Chl-a concentration $\left(\mathrm{mg} \cdot \mathrm{m}^{-3}\right)$ in coastal European seas for the period of 1998-2009 was presented as calculated from the Global Ocean GSM-MyOcean ocean-colour product (Figure 2(a)) and in-situ data (Figure 2(b)). CSI023(+) was shown in the two formats: 1) CSI023(+) pan-European trend indicator and 2) CSI023(+) Chl-a areas trend indicator in the Mediterranean Sea. Paragraphs 4.2 to 4.4 present the abovementioned results.

\subsection{Validation against In-Situ Data}

In some locations the ocean-colour products differ greatly from the in-situ observations; one reason could be that in some cases in-situ data quality could be low (i.e. problem with calibration of instruments is expected due to the large number of data providers; some geographical coordinates of the single profiles were provided without precise rounding at the minutes value, and therefore with possible uncertainties on the geographical location of the sampling position) and this information is not provided with the Eionet datasets (i.e. data are not flagged for different quality levels). Moreover as explained in paragraph 2.1, ocean colour data used in the study was based on open ocean algorithms and therefore was not as accurate as needed in the very coastal zone where part of the in-situ data have been collected. For these reasons we expect that the validation will be worse in some coastal regions.

The comparison of Med Regional SeaWiFS RANMyOcean with in-situ data in the Mediterranean Sea shows a correlation which are higher than that observed with the Global Ocean GSM-MyOcean data (Figure 8 and Table 3). Bias of the Mediterranean regional products presented in Table 3 is lower than that of the Global product. The regional product which is also refers to as Med Regional SeaWiFS RAN-MyOcean thus seems to be preferable with respect to Global Ocean GSMMyOcean in comparison with in-situ data.

The comparison of in-situ and satellite Chl-a trends shows that satellite products are able to capture the sign of the in-situ trend in the majority of the stations $(68 \%)$ but the intensity of trends are not well captured by the satellite products.

\subsection{Spatial Distribution of Chl-a Concentration in Coastal European Seas (Chl-a Summer Climatology)}

The European seas summer Chl-a mean $\left(\mathrm{mg} \cdot \mathrm{m}^{-3}\right)$ over the period of 1998-2009 (Figure 2 left panel) indicated the highest values in the Baltic Sea, in the southern North Sea and the Western Black Sea. The lowest values were reached in the Mediterranean Sea open-ocean areas. The Irish Sea, Bay of Biscay and Portuguese Atlantic areas also show high Chl-a values, although these are lower than the Baltic and North Sea. In the Mediterranean the low Chl-a values show a negative West-to-east gradient: this is very well known for this area $[35,36]$. The Black Sea shows highest values in the North-western part of the basin (Danube area). The climatology based on ocean colour products (Global Ocean GSM-MyOcean) presented in this paper shows similar patterns of Chl-a compared to the ones based on SeaWIFS data [22] but lower concentrations of Chl-a are detected.

The in-situ climatology (Figure 2 right panel) reveals the sampling problem of the in-situ dataset: large areas with no data are present in the Black Sea, Mediterranean Sea, Atlantic Ocean, North Sea and Norwegian Sea. The poor coverage of the in-situ observations is due to the lack of monitoring programs and to the possible problems in the reporting systems.

The in-situ and ocean colour climatologies show similar values in most of the Baltic Sea with the exceptions of the Gulf of Finland and Gulf of Riga where ocean-colour products underestimate in-situ values. The southern part of the North Sea in-situ and ocean colour show similar mean values, although there is still an evident underestimation of the values by the satellite products. In the northern part of the Adriatic Sea, the in-situ and oceancolour products show similar values, while in the southern areas of the Adriatic ocean colour once again underestimates the in-situ values. In like manner, in the Ligurian Sea, the ocean-colour products underestimate in-situ observations, as they also do in the Tyrrhenian Sea. The fact that the in situ and ocean colour climatologies show similar values is encouraging because it will allow to complement the in-situ climatology with the ocean colour one thus providing a larger coverage and a full PanEuropean picture of Chl-a mean values in the European Seas.

\subsection{Comparison of Global Ocean GSM-MyOcean, Global Ocean SeaWiFS RAN-MyOcean and Med Regional SeaWiFS RAN-MyOcean Trends}

To control the results of CSI023(+) obtained with Global Ocean GSM-MyOcean we decide to perform a comparison between the Chl-a trends obtained with Global Ocean GSM-MyOcean and the ones obtained with Global Ocean SeaWiFS RAN-MyOcean.

In Figure 3 we show both significant and non-significant trends to allow a better comparison of the two trends. Global Ocean GSM-MyOcean and Global Ocean 
SeaWiFS RAN-MyOcean trends show similar patterns but the intensity of trends detected using Global Ocean SeaWiFS RAN-MyOcean time series are higher than the ones obtained using Global Ocean GSM-MyOcean. Both products show positive trends in the northern part of the North Sea, in the North East Atlantic, in the central and southern part of the Baltic Sea, as well as in the Bay of Biscay, in the Alboran Sea, in the Ligurian Sea, in the southern part of the Gulf of Lion, in the southern Adriatic Sea and in the North-East Ionian Sea. Moreover negative trends were detected by the two datasets in the Black Sea, in most of the Mediterranean Sea, in part of the NorthEast Atlantic, in the English Channel and in the central part of the North Sea. Although, the main differences are found in the Gulf of Botnia and Gulf of Finland where Global Ocean SeaWiFS RAN-MyOcean shows negative trends while Global Ocean GSM-MyOcean shows positive trends. Besides, in the Skagerrak, Norwegian coasts and, in the English Channel, in the Po River mouth and in the western part of the Black Sea SeaWiFS showed similar negative sign but stronger negative trends in respect to GMS product. The positive trend in the central part of the Baltic Sea is stronger in Global Ocean SeaWiFS RAN-MyOcean than in the Global Ocean GSM-MyOcean dataset.

The comparison of the Global Ocean SeaWiFS RANMyOcean and the Global Ocean GSM-MyOcean reveals a general similarity among the two datasets and therefore the usage of the merged product (Global Ocean GSM-MyOcean), which offers longer time series, could be taken into account for continuing the update of the indicator also after the end of Sea-WIFS. On the contrary the differences highlighted in the Chl-a trends should be taken into account to identify areas of larger uncertainties where the satellite products might be less appropriate to estimate Chl-a trends (i.e. Baltic Sea).

The Chl-a trend analysis was also carried out in the Mediterranean Sea using the regional products Med Regional SeaWiFS RAN-MyOcean ocean-colour dataset for the period of 1998-2009 and thus was presented in Figure 4. Results obtained with the regional product appear similar to the ones obtained using the global product Global Ocean GSM-MyOcean presented in Figure 3(b). In the western Mediterranean, global and regional satellite products show similar trends. Some differences were detected in the Tyrrhenian Sea along the eastern coasts of Sardinia and Corsica where the global product presents positive trends not shown in the regional product. In the southern part of the Tyrrhenian basin, the regional product shows positive trends areas that appear larger than the ones of the global product. The Adriatic Sea trends appear very similar in the two datasets. In the Ionian Sea the two products show similar trends with the exception of a positive trend area south of Sicily that appears larger in the regional product, the Gulf of Gabes in which the regional product shows a negative trend and the Gulf of Sirte where the regional product highlights a positive trend that was not clearly visible in the global product. In the central part of the Levantine Basin, in southern part of the Aegean Sea and in front of the Nile River mouth the regional product show stronger positive trends respect to the global product. The differences among the two products Med Regional SeaWiFS RAN-MyOcean and Global Ocean GSM-MyOcean might be due to the fact that the global product consists of a merged product and uses different satellites (MERIS, MODIS and SEAWIFS) while the regional product is based on the SeaWiFS satellite product. Moreover the SeaWiFS regional product is based on a regional algorithm specifically calibrated for the Mediterranean Sea.

The results of the regional product Med Regional SeaWiFS RAN-MyOcean were also compared with the ones obtained in the Mediterranean with the Global Ocean SeaWiFS RAN-MyOcean. Results appear very similar in the entire basin; although small differences were detected in front of the Po River mouth where the regional product shows weaker negative trend values, while along the Italian Adriatic coast the negative trend appears stronger in the regional product. In the Gulf of Gabes the regional product shows a negative trend that which was detected as positive trend in the global SeaWiFS product. In front of the Nile River mouth the regional product detects a stronger positive trend with respect to the one shown in the global product.

The main difference among the global (Global Ocean SeaWiFS RAN-MyOcean) and regional (Med Regional SeaWiFS RAN-MyOcean) is that the first is produced using the global ocean algorithm while the second is produced using the regional alrogithm (MedOC4, [28]). This difference might be the main reason for the differences detected in the trends. The use of regional product (Med Regional SeaWiFS RAN-MyOcean) is recommended because the algorithm (MedOC4, [28]) used to calculate it is calibrated for the specific sea (i.e. Mediterranean Sea in our study).

\section{4. $\operatorname{CSI023(+)}$}

In this section we present $\mathrm{CSIO23}(+)$ analysis in terms of pan-European trends map (based on the Global Ocean GSM-MyOcean product) and Chl-a area trends in the Mediterranean Sea (based on Med Regional SeaWiFS RAN-MyOcean product).

\subsubsection{CSI023(+) Pan-European Trends}

CSI023(+) over the period of 1998-2009 was presented in Figure 5 (a). It is worthy to note that the STD of Chl-a $\left(\mathrm{mg} \cdot \mathrm{m}^{-3}\right)$ is naturally high in regions of high Chl-a. With 
regard to relative changes, CSI023(+), provides a PanEuropean picture that highlights the spatial variability of the trends and minimizes the natural Chl-a concentration differences among the European Seas.

CSI023(+) shows areas with decreasing Chl-a concentrations in the Black Sea, the Eastern Mediterranean, the southern part of the Western Mediterranean and the English Channel. Areas with increasing trends were observed in the northern Ionian Sea, the off-shore area of the Bay of Biscay, the North-East Atlantic, the North Sea, the Kattegat and the Baltic, trend values only above the $95 \%$ confidence level were presented, and therefore white areas in the map correspond to grid points with no significant trend.

The CSI023(+) positive trends in the central part of the Baltic Sea are consistent to the results presented in [13] but CSIO23(+) seems to overestimate $\mathrm{CHl}-\mathrm{a}$ trends in the Gulf of Bothnia. In interpreting the results in the Baltic Sea we need to consider that it is known that the global ocean products used in this study are not calibrated for the Case2 waters of the Baltic Sea and there fore large error are expected in this area.

In the Mediterranean Sea CSI023(+) did not show significant Chl-a trends in most of the basin. Negative values of CSI023(+) were detected in several off-shore regions (South of Sardinia, in the Ionian Sea, and in the Southern-Eastern Levantine Sea) and in the coastal reagion of the Eastern Mediterranean. The negative trend of Chla might be related to the general warming of Mediterranean waters [37,38] that leads to an intensification of water column stratification that consequently limits the uplift of nutrients from the deeper water column below the nutricline.

In the analysis performed with the regional product (Med Regional SeaWiFS RAN-MyOcean) the results of the slope of the trends presented in Figure 4 (statistical significance was not calculated, both significant and non significant trends are shown in this figure) some of the off-shore positive trends of Chl-a (i.e. in the Northern Ionian Sea, in the Western and Central Levantine) are possibly correlated with the intensification of cyclonic activities identified in the same areas in a similar period 1997-2006 [39] that could contribute to upwelling processes. In the Most of the off-shore negative trends are detected in areas (i.e. Algerian Basin, Central and Southern Ionian Sea) that are characterized by anti-cyclonic activities [39].

The negative trend in the Black Sea has been previously described in previous studies [22]. The variations of the ecosystem of the Black Sea in the last decades have been reported [40-42] and they are related to complex set of pressures, including impacts from large scale climatic variability [43], variations in the nutrient and pollutant inputs $[44,45]$. Also the appearance and evolu- tion of invasive species $[46,47]$ was very relevant for the Black Sea ecosystem changes.

The Chl-a standard deviation over the period of 19982009 presented in Figure 5(b) shows that natural variability is high in the Baltic, the North Sea, the North-East Atlantic shelf areas and the northern regions of the Mediterranean and the Black Sea. Chl-a natural variability appears low in the Mediterranean, with a minimum in the Eastern Mediterranean basin.

\subsubsection{CSI023(+) Chl-a Area Trends}

In the Mediterranean, a special application of CSI023(+) was performed for the period of 1998-2009 when a regional ocean-colour product at high spatial resolution was available. $\mathrm{CSIO23(+)}$ is calculated for each Chl-a area and results for this special application of CSI023(+) are presented with the classic CSI023 indicator mapping showing the percentage of decreasing, increasing and no-trend stations (Figures 6). The CSI023(+) Chl-a areas indicator for the Mediterranean Sea shows that about $52 \%$ of Chl-a areas do not show significant trends (i.e., significant trends found for less than $10 \%$ of the grid points in each area). Increasing Chl-a trends (i.e., found for equal or more than $10 \%$ of the grid points in each area) were detected in 9\% (12) of the Chl-a areas (in Egypt, Greece, Tunisia, Malta and Turkey coast lines) see Figures 6(e) and (f). The increasing Chl-a trend in the coastal areas of Egypt, higher in the in-shore Chl-a area than in the off-shore Chl-a area (Figure 6(f)), could be related to the discharge of nutrients from the Nile. The increasing trend in Greece is detected in the Epirus areas (North West Greece) and might be related to nutrient river inputs such as the ones from Kalamas River in which eutrophication signs were obvious during the warm period [48].

Decreasing significant $\mathrm{Chl}-\mathrm{a}$ trends (i.e., found for equal or more than $10 \%$ of the grid points in each area) were detected in the 39\% (53) Ch-a areas: Italian coasts in the Adriatic, Slovenian coasts (Figures 6(d)), Greek coasts in the northern Aegean Sea and in the northern Ionian Sea (Figures 6(e)), Italian coast in the northern Tyrrhenian Sea and Ligurian Sea (Figure 6(c)), Algerian coasts (Figure 6(e)), Spanish coasts in the Ebro area, Catalan area and in the Alboran Sea (Figure 6(a)), Maltese coasts (Figure 6(f)), Turkish coasts in the northern Levantine and in the Aegean Sea (Figure 6(e)), Sicily coasts in the Ionian Sea (Figure 6(c)), Tunisian coasts (Figure 6(f)), French coasts in the Rhone area (Figure 6(b)), Syrian coasts (Figure 6(e)), Libyan coasts (Figure 6(f)) and Israeli coasts (Figure 6(e)).

The decreasing Chl-a trends in the coastal areas in the Mediterranean Sea are possibly related to a combination of factors such as the reduction of river flow due to agriculture and industrial use [49], impact of climate change 
(i.e. reduction of rivers flow and increase of ocean temperature) and the implementation of EU policies for the reduction of nutrients loads in the water bodies (i.e. WFD). In this sense the decreasing trend of Chl-a in the Ebro coastal area (see Chl-a area Ebro-IBS IN and OFF) could be related to the decrease in nutrients concentration and flow [49]. Also in the Northern Adriatic Sea our results confirm the decrease in Chl-a concentration as discussed in [50] that might be related to the reduced freshwater discharges, together with phosphorus being banned by Italian law in the mid-1980s and the general improvement in sewage treatment.

\section{Conclusions}

The CSI023(+) indicator based on the ocean colour products has been developed to contribute to the state-ofthe-environment assessment and, in particular, to monitor eutrophication trends. We performed the comparison of Chl-a concentrations and trends estimated through remote sensing with in-situ ones. The comparison presented indicated that the global ocean-colour algorithm seems to underestimate Chl-a concentration (Figure 2). To evaluate the performance of satellite products to estimate Chla trends at Pan-European Scale, we compared different satellite products (i.e. Global Ocean GSM-MyOcean and Global Ocean SeaWiFS RAN-MyOcean), and found that the trends intensity detected using SeaWiFS time series were higher with the GSM once, nevertheless, GSM and SeaWiFS trends show similar patterns. The differences highlighted in the northern Baltic Sea point out the lower confidence of the satellite products in detecting Chl-a trends in this region. The comparison of the global products (i.e. Global Ocean GSM-MyOcean) with the regional product available in the Mediterranean Sea Med Regional SeaWiFS RAN-MyOcean show similarities in the general patterns while specific differences have been highlighted. The comparison of Global Ocean SeaWiFS RAN-MyOcean and the corresponding regional product Med Regional SeaWiFS RAN-MyOcean show strong similarities. Thus, some local differences were discussed.

The CSI023(+) indicator based on the Global Ocean GSM-MyOcean shows the capability of detecting significant negative and positive terms for Chl-a trends in European seas, thereby allowing us to complement the in-situ CSI023 covering only part of the European coastal areas. The CSI023(+) indicator also shows a large area with decreasing Chl-a concentrations in the Black Sea, the Mediterranean, the English Channel and the northern part of the North Sea; whereas a large area with increasing trends were observed in the Bay of Biscay and the Baltic. Trends estimated by ocean colour products are compared with trends estimated by in-situ data (Figures 11 and 12). Hence, they show a clear differences as well as the capability of ocean colour products to capture the sign of the in-situ trend in the majority of the comparison locations. Moreover, the Med Regional SeaWiFS RANMyOcean and CNR regional daily dataset used in the Mediterranean Sea seems to show a good comparison with in-situ data (Table 3 and Figure 10). Therefore, further investigations are needed to be carried out to compare the trends at the level of Chl-a areas when more coastal in-situ Chl-a time series will be available and when new satellite products built upon coastal algorithm will be available. Validation should continue in the future, perhaps with a dedicated data-collection exercise. Chl-a area analysis offers the possibility of synthesizing CSI023 $(+)$ information thus focuses attention on coastal areas. The analysis also revealed the need for regional oceancolour products availability to develop support of the EEA indicator. In addition there is potential in a long-term trend analysis based on ocean colour, as large-scale, and in some cases even regional-scale, changes appear to be captured by the satellite images. It is clear, however, that in order to build confidence in this analysis it needs to be based on the best possible regional products. As not all the used MyOcean products consist of complete reprocessed data, it is planned that as soon as new regional datasets are available they will be used to calculate CSI023(+).

Although Global Ocean GSM-MyOcean and Med Regional SeaWiFS RAN-MyOcean and CNR were available as daily products, not all the information from ocean colour has been used yet, because, CSI023(+) using summer mean values in analogy with classical in-situ CSI023. However, for the future we plan to use full daily satellite Chl-a estimate resolution to evaluate changes in the statistical significance of the results.

\section{Acknowledgements}

The Work of this research has been carried out within the framework of the European Topic Centre on Inland, Coastal and Marine Waters (ETC/ICM)

(http://icm.eionet.europa.eu) and MyOcean

(www.myocean.eu) projects. Authors would like to thank Damiano Delrosso for supporting revision phase of this work. Authors would also like to thank the colleagues of the Operational Oceanography group of INGV in Bologna for the fruitful collaboration and discussions in the preparation of this work.

\section{REFERENCES}

[1] J. G. Ferreira, J. H. Andersen, A. Borja, S. B. Bricker, J. Camp, M. C. da Silva, E. Garcés, A.-S. Heiskanen, C. Humborg, L. Ignatiades, C. Lancelot, A. Menesguen, P. Tett, N. Hoepffner and U. Claussen, "Overview of Eutrophication Indicators to Assess Environmental Status 
within the European Marine Strategy Framework Directive, Estuarine," Coastal and Shelf Science, Vol. 93, No. 2, 2011, pp. 117-131.

[2] S. B. Bricker, C. G. Clement, D. E. Pirhalla, S. P. Orlando and D. R. G. Farrow, "National Estuarine Eutrophication Assessment. Effects of Nutrient Enrichment in the Nation's Estuaries," NOAA, National Ocean Service, Special Projects Office and National Centers for Coastal Ocean Science, Silver Spring, 1999.

http://ian.umces.edu/neea/pdfs/eutro_report.pdf

[3] S. B. Bricker, J. G. Ferreira and T. Simas, "An Integrated Methodology for Assessment of Estuarine Trophic Status," Ecological Modelling, Vol. 169, No. 1, 2003, pp. 39-60.

[4] S. B. Bricker, S. V. Smith, J. G. Ferreira, A. M. Nobre, E. Dettmann and J. Latimer, "Assessment of Eutrophication: A Comparison of Methods Applied to Barnegat Bay," Estuarine Research Federation 2005, Session SYM-06: Managing River Basins and Estuaries: An International Assessment of Approaches and Progress, 2005. http://www.eutro.org/presentations/Barnegat $\% 20$ ERF\%2 02005\%20SYM-06\%20final.pdf

[5] S. B. Bricker, B. Longstaff, W. Dennison, A. Jones, K. Boicourt, C. Wicks and J. Woerner, "Effects of Nutrient Enrichment in the Nation's Estuaries: A Decade of Change, National Estuarine Eutrophication Assessment Update," National Centers for Coastal Ocean Science, Silver Spring, 2007.

http://ccma.nos.noaa.gov/publications/eutroupdate/

[6] S. B. Bricker, B. Longstaff, W. Dennison, A. Jones, K. Boicourt, C. Wicks and J. Woerner, "Effects of Nutrient Enrichment in the Nation's Estuaries: A Decade of Change," Harmful Algae, Vol. 8, No. 1, 2008, pp. 21-32.

[7] G. Kowalewska, B. Wawrzyniak-Wydrowska and M. Szymczak-Zyla, "Chlorophyll a and Its Derivatives in Sediments of the Odra Estuary as a Measure of Its Eutrophication," Marine Pollution Bulletin, Vol. 49, No. 3, 2004, pp. 148-153.

[8] U. Claussen, W. Zevenboom, U. Brockmann, D. Topcu and P. Bot, "Assessment of the Eutrophication Status of Transitional, Coastal and Marine Waters within OSPAR," Hydrobiologia, Vol. 629, No. 1, 2009, pp. 49-58.

[9] M. Garmendia, M. Revilla, J. Bald, J. Franco, A. LazaMartínez, E. Orive, S. Seoane, V. Valencia and Á. Borja, "Phytoplankton Communities and Biomass Size Structure (Fractionated Chlorophyll 'a'), along Trophic Gradients of the Basque Coast (northern Spain)," Biogeochemistry, Vol. 106, No. 2, 2011, pp. 243-263. doi:10.1007/s10533-010-9445-2

[10] J. Carstensen and P. Henriksen, "Phytoplankton Biomass Response to Nitrogen Inputs: A Method for WFD Boundary Setting Applied to Danish Coastal Waters," Hydrobiologia, Vol. 633, No. 1, 2009, pp. 137-149.

[11] M. Devlin, M. Best, D. Coates, E. Bresnan, S. O’Boyle, R. Park, J. Silke, C. Cusack and J. Skeats, "Establishing Boundary Classes for the Classification of UK Marine Waters Using Phytoplankton Communities," Marine Pollution Bulletin, Vol. 55, No. 1-6, 2007, pp. 91-103.

[12] M. Devlin, J. Barry, S. Painting and M. Best, "Extending the Phytoplankton Tool Kit for the UK Water Framework
Directive: Indicators of Phytoplankton Community Structure," Hydrobiologia, Vol. 633, No. 1, 2009, pp. 151-168.

[13] HELCOM, "Eutrophication in the Baltic Sea: An Integrated Thematic Assessment of the Effects of Nutrient Enrichment and Eutrophication in the Baltic Sea Region," Baltic Sea Environment Proceedings No. 115A, Helsinki Commission, Helsinki, 2009, pp. 1-20.

[14] J. G. Ferreira, S. B. Bricker and T. C. Simas, "Application and Sensitivity Testing of an Eutrophication Assessment Method on Coastal Systems in the United States and European Union," Journal of Environmental Management, Vol. 82, No. 4, 2007, pp. 433-445.

[15] OSPAR, "Second OSPAR Integrated Report on the Eutrophication Status of the OSPAR Maritime Area," OSPAR Publication, 2008.

[16] S. Nixon, "Eutrophication and the Macroscope," Hydrobiologia, Vol. 629, No. 1, 2009, pp. 5-19.

[17] A. Morel and L. Prieur, "Analysis of Variations in OceanColour," Limnology Oceanography, Vol. 22, No. 4, 1977 , pp. 709-722. doi:10.4319/1o.1977.22.4.0709

[18] H. Gordon and A. Morel, "Remote Assessment of Ocean Colour for Interpretation of Satellite Visible Imagery: A Review,” Springer-Verlag, Berlin, 1983.

[19] L. Prieur and S. Sathyendranath, "An Optical Classification of Coastal and Oceanic Waters Based on the Specific Spectral Absorption Curves of Phytoplankton Pigments, Dissolved Organic Matter and Other Particulate Materials," Limnology Oceanography, Vol. 26, No. 4, 1981. pp. 671-689. doi:10.4319/10.1981.26.4.0671

[20] D. Antoine, A. Morel, B. Gentili, H. R. Gordon, V. F. Banzon, R. H. Evans, J. W. Brown, S. Walsh, W. Baringer and $\mathrm{A}$. Li, "In Search of Long-Term Trends in Ocean Color," Eos, Transactions American Geophysical Union, Vol. 84, No. 32, 2003, pp. 301-309. doi:10.1029/2003EO320002

[21] C. Beaulieu, S. A. Henson, J. L. Sarmiento, J. P. Dunne, S. C. Doney, R. R. Rykaczewski and L. Bopp, "Factors Challenging Our Ability to Detect Long-Term Trends in Ocean Chlorophyll," Biogeosciences, Vol. 10, 2013, pp. 2711-2724. doi:10.5194/bg-10-2711-2013

[22] V. Vantrepotte and F. Melin, "Temporal Variability in SeaWiFS Derived Apparent Optical Properties in European Seas," Continental Shelf Research, Vol. 30, No. 3-4, 2010, pp. 319-334. doi:10.1016/j.csr.2009.11.012

[23] V. Vantrepotte and F. Melin, "Inter-Annual Variations in the SeaWiFS Global Chlorophyll a Concentration (19972007)," Deep Sea Research Part I: Oceanographic Research Papers, Vol. 58, No. 4, 2011, pp. 429-441. doi:10.1016/j.dsr.2011.02.003

[24] S. Maritorena, D. A. Siegel and A. Peterson, "Optimization of a Semi-Analytical Ocean Colour Model for Global Scale Applications," Applied Optics, Vol. 41, No. 15, 2002, pp. 2705-2714. doi:10.1364/AO.41.002705

[25] S. Maritorena and D. A. Siegela, "Consistent Merging of Satellite Ocean Colour Data Sets Using a Bio-Optical Model," Remote Sensing of Environment, Vol. 94, No. 4, 2005, pp. 429-440. doi:10.1016/i.rse.2004.08.014

[26] S. Maritorena, O. H. Fanton d'Andonb, A. Mangin and D. 
A. Siegel, "Merged Satellite Ocean Colour Data Products Using a Bio-Optical Model: Characteristics, Benefits and Issues," Remote Sensing of Environment, Vol. 114, No. 8, 2010, pp. 1791-1804.doi:10.1016/j.rse.2010.04.002

[27] J. E. O'Reilly and 24 co-authors, "Ocean Colour Chlorophyll-a Algorithms for SeaWiFS, OC2 and OC4: Version 4," In: S. B. Hooker and E. R. Firestone, Eds., SeaWiFS Post Launch Calibration and Validation Analyses, Vol. 11, NASA Goddard Space Flight Center, Greenbelt, 2000, pp. 9-23.

[28] G. Volpe, R. Santoleri, V. Vellucci, M. Ribera d'Alcalà, S. Marullo and F. D'Ortenzio, "The Colour of the Mediterranean Sea: Global Versus Regional Bio-Optical Algorithms Evaluation and Implication for Satellite Chlorophyll Estimates," Remote Sensing of Environment, Vol. 107, No. 4, 2007, pp. 625-638. doi:10.1016/j.rse.2006.10.017

[29] G. Volpe, S. Colella, V. Forneris, C. Tronconi and R. Santoleri, "The Mediterranean Ocean Colour Observing System-System Development and Product Validation," Ocean Science, Vol. 8, No. 5, 2012, pp. 869-883.

[30] J. Sun, R. E. Eplee Jr., X. Xiong, T. Stone, G. Meister and C. R. McClain, "MODIS and SeaWiFS On-Orbit Lunar Calibration," Proceedings of SPIE, Vol. 7081, Earth Observing Systems XIII, 2008, Article ID: 70810Y. doi: $10.1117 / 12.795338$

[31] R. E. Eplee Jr., X. Xiong, J. Sun, G. Meister and C. McClain, "The Cross Calibration of SeaWiFS and MODIS Using On-Orbit Observations of the Moon, Earth Observing Systems XIV," Proceedings of the Society of Photo-Optical Instrumentation, Vol. 7452, No. 74520X, 2009, p. 74520X-9. doi:10.1117/12.825160

[32] P. K. Sen, "Estimates of the Regression Coefficient Based on Kendall's Tau," Journal of the American Statistical Association, Vol. 63, No. 324, 1968, pp. 1379-1389. doi:10.1080/01621459.1968.10480934

[33] T. Salmi, A. Määttä, P. Anttila, T. Ruoho-Airola and T. Amnell, "Detecting Trends of Annual Values of Atmospheric Pollutants by the Mann-Kendall Test and Sen's Slope Estimates-The Excel Template Application Makesens," Ilmanlaadun julkaisuja Publikationer om luftkvalitet Publications on air quality No. 31, Ilmatieteen laitos, Meteorologiska Institutet, Finnish Meteorological Institute, Helsinki, 2002.

[34] R. O. Gilbert, "Statistical Methods for Environmental Pollution Monitoring," John Wiley and Sons, New York, 1987.

[35] I. Siokou-Frangou, U. Christaki, M. G. Mazzocchi, M. Montresor, M. R. D'Alcalà, D. Vaque and A. Zingone, "Plankton in the Open Mediterranean Sea: A Review," Biogeosciences, Vol. 7, No. 5, 2010, pp. 1543-1586.

[36] F. D'Ortenzio and M. R. D'Alcalà, "On the Trophic Regimes of the Mediterranean Sea: A Satellite Analysis," Biogeosciences, Vol. 6, No. 2, 2009, pp. 139-148.

[37] J.-P. Bétoux, B. Gentili and D. Tailliez, "Warming and Freshwater Budget Change in the Mediterranean since the 1940s, Their Possible Relation to the Greenhouse Effect," Geophysical Research Letters, Vol. 25, No. 7, 1998, pp. 1023-1026. doi:10.1029/98GL00724
[38] J. Lelieveld, H. Berresheim, S. Borrmann, P. J. Crutzen, F. J. Dentener, H. Fischer, et al., "Global Air Pollution Crossroads over the Mediterranean," Science, Vol. 298, No. 5594, 2002, pp. 794-799. doi:10.1126/science. 1075457

[39] S. Marullo, V. Artale and R. Santoleri, "The SST Multidecadal Variability in the Atlantic-Mediterranean Region and Its Relation to AMO," Journal of Climate, Vol. 24, No. 16, 2011, pp. 4385-4401. doi:10.1175/2011JCLI3884.1

[40] N. Pinardi, M. Zavatarelli, M. Adani, G. Coppini, G. Fratianni, P. Oddo, M. Tonani, V. Lyubartsev, S. Dobricic and A. Bonaduce, "Mediterranean Sea Large Scale Low Frequency Ocean Variability and Water Mass Formation Rates from 1987 to 2007: A Retrospective Analysis," Progress in Oceanography, 2013. (in Press)

[41] A. I. Ginzburg, A. G. Kostianoy and N. A. Sheremet, "Seasonal and Interannual Variability of the Black Sea Surface Temperature as Revealed from Satellite Data (1982-2000)," Journal of Marine Systems, Vol. 52, No. 1-4, 2004, pp. 33-50.

[42] S. K. Konovalov and J. W. Murray, "Variations in the Chemistry of the Black Sea on a Time Scale of Decades (1960-1995)," Journal of Marine Systems, Vol. 31, No. 1-3, 2001, pp. 217-243.

[43] A. Kideys, "All and Rise of the Black Sea Ecosystem," Science, Vol. 297, No. 5586, 2002, pp. 1482-1484.

[44] T. Oguz, J. W. Dippner and Z. Kaymaz, "Climatic Regulation of the Black Sea Hydro-Meteorological and Ecological Properties at Interannual-to-Decadal Time Scales," Journal of Marine Systems, Vol. 60, No. 3-4, 2006, pp. 235-254.

[45] C. Humborg, V. Ittekkot, A. Cociasu and B. Bodungen, "Effect of Danube River Dam on Black Sea Biogeochemistry and Ecosystem Structure," Nature, Vol. 386, No. 6623, 1997, pp. 385-388.

[46] O. A. Yunev, S. Moncheva and J. Carstensen, "LongTerm Variability of Vertical Chlorophyll a and Nitrate Profiles in the Open Black Sea: Eutrophication and Climate Change," Marine Ecology Progress Series, Vol. 294, 2005, pp. 95-107.

[47] A. E. Kideys and Z. Romanova, "Distribution of Gelatinous Macrozooplankton in the Southern Black Sea during 1996-1999," Marine Biology, Vol. 139, No. 3, 2001, pp. $535-547$.

[48] A. E. Kideys, A. Roohi, S. Bagheri, G. Finenko and L. Kamburska, "Impacts of Invasive Ctenophores on the Sheries of the Black Sea and Caspian Sea," Oceanography, Vol. 18, No. 2, 2005, pp. 76-85.

[49] I. Kagalou, I. Leonardos, C. Anastasiadou and C. Neofytou, "The DPSIR Approach for an Integrated River Management Framework. A Preliminary Application on a Mediterranean Site (Kalamas River-NW Greece)," Water Resource Management, Vol. 26, No. 6, pp. 1677-1692. doi:10.1007/s11269-012-9980-9

[50] C. Ibáñez, N. Prat, C. Duran, M. Pardos, A. Munné, A. Ginebreda, L. Tirapu, R. Andreu, N. Caiola, N. Cid, H. Hampel, R. Sanchez and R. Trobajo, "Changes in Dissolved Nutrients in the Lower Ebro River: Causes and 
Consequences," Limnetica, Vol. 27, No. 1, 2008, pp. 53-64.

[51] P. Mozetič, C. Solidoro, G. Cossarini, G. Socal, R. Precali, J. France, F. Bianchi, C. de Vittor, N. Smodlaka and S. F. Umani, "Recent Trends towards Oligotrophication of the Northern Adriatic: Evidence from Chlorophyll a Time Series," Estuaries and Coasts, Vol. 33, No. 2, 2010, pp. 362-375. doi:10.1007/s12237-009-9191-7 


\section{Annex I Chl-a Areas Description}

As explained in the study in paragraph $2.4 \mathrm{Chl}$-a areas were defined in the Mediterranean Sea and they are 68. Chla areas were defined using information on the River Basin Districts (RBDs), and political borders when RBDs were not defined. Moreover, 18 open-ocean sub-basins were identified in the Mediterranean and used to design the Chl-a areas. When possible, within each
Chl-a area two sub-areas are were defined: a coastal one (IN), from the coast to a depth of 30 metres and an offshore one (OFF), from a depth of 30 to 200 metres. A name composed of 3 parts was associated with each single Chl-a area as following: 1) name of the RBD or name of the country; 2) name of the sub-basin; 3) 'IN' if it is the inshore part of the Chl-a area or 'OFF' if it is the offshore part of the Chl-a area.

Chl-a areas are listed in the table below.

Table. Names of the Chl-a areas

\begin{tabular}{|c|c|}
\hline Chla Areas names & Chla Areas names \\
\hline Cuencas Med. Andaluzas & Western Peloponnese-SIO \\
\hline Seguera-ALS & Western Peloponnese-AEG \\
\hline Jucar-ALS & Eastern Peloponnese-AEG \\
\hline Jucar-IBS & Nothern Peloponnese-AEG \\
\hline Ebro-IBS & Eastern Sterea Ellada-NIO \\
\hline Cuencas Internas Catalanas-IBS & Attica-AEG \\
\hline Cuencas Internas Catalanas-GLI & Eastern Sterea Ellada-AEG \\
\hline Rhone et...-GLI & Western Macedonia \\
\hline Rhone et...-LGS & Central Macedonia-AEG \\
\hline Appennino Sett.-LGS-1 & Eastern Macedonia \\
\hline Serchio-LGS & Turkey-AEG \\
\hline Appennino Sett.-LGS-2 & Turkey-NBL \\
\hline Appennino Sett.-NTY & Siria-SLB \\
\hline Appennino Cent.-NTY & Lebanon-SLB \\
\hline Appennino Cent.-STY & Israel-SLB \\
\hline Appennino Merd.-STY & Egypt-SLB \\
\hline Sicilia-STY & Lybia-SLB \\
\hline Sicilia-SSI & Lybia-GSY \\
\hline Sicilia-SIO & Lybia-GGA \\
\hline Appennino Merd.-NIO & Tunisia-GGA \\
\hline Appennino Merd.-SAD & Tunisia-SSI \\
\hline Appennino Cent.-SAD & Tunisia-ALG \\
\hline Appennino Cent.-NAD & Algeria-ALG \\
\hline Appennino Sett.-NAD & Algeria-ALS \\
\hline Padano-NAD & Marocco-ALS \\
\hline Alpi Orientali-NAD & Balearic-APB \\
\hline Vodno-NAD & Corsica-APB \\
\hline Croatia-NAD & Corsica-NTY \\
\hline Croatia-SAD & Malta-SSI \\
\hline Montenegro-SAD & Malta-SIO \\
\hline Albania-SAD & Creta-AEG \\
\hline Epirus-1-NIO & Cipro-NLB \\
\hline Western Sterea Ellada-NIO & Sardegna-SAD \\
\hline Nothern Peloponnese-SIO & Sardegna-STY \\
\hline
\end{tabular}

